\title{
The Impact and Effectiveness of Fiscal Incentives for R\&D
}

Compendium of Evidence on the Effectiveness of Innovation Policy Intervention

Christian Köhler, Centre for European Economic Research (ZEW) Philippe Larédo, MIoIR and Université Paris-Est (ENPC, LATTS) Christian Rammer, Centre for European Economic Research (ZEW)

Manchester Institute of Innovation Research Manchester Business School, University of Manchester http://research.mbs.ac.uk/innovation/ 
This report is part of the Compendium of Evidence on the Effectiveness of Innovation Policy Intervention Project led by the Manchester Institute of Innovation Research (MIoIR), University of Manchester. The project is funded by the National Endowment for Science, Technology and the Arts (NESTA) - an independent body with the mission to make the UK more innovative.

The compendium is organised around 20 innovation policy topics categorised primarily according to their policy objectives. Currently, some of these reports are available.

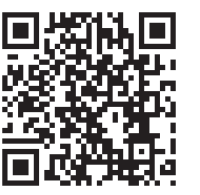

All reports are available at http://www.innovation-policy.org.uk. Also at this location is an online strategic intelligence tool with an extensive list of references that present evidence for the effectiveness of each particular innovation policy objective. Summaries and download links are provided for key references. These can also be reached by clicking in the references in this document. 


\section{Table of Contents}

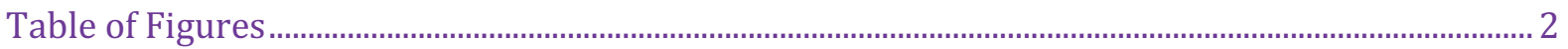

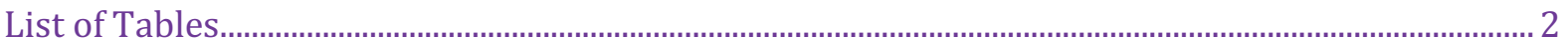

Executive Summary .............................................................................................................................. 3

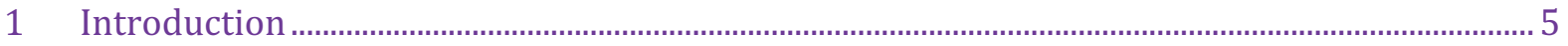

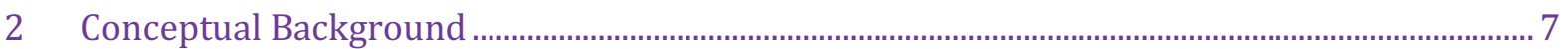

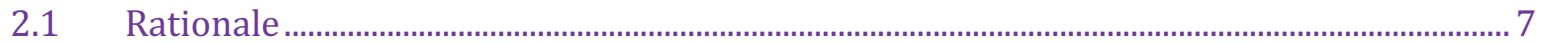

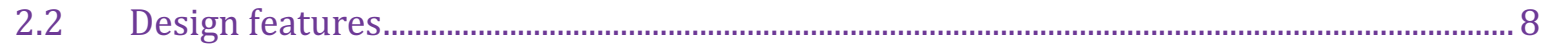

2.3 Fiscal incentives as complex multi-objectives policy instruments..................................... 12

3 Effectiveness of R\&D tax incentives: findings from evaluation studies ...................................... 13

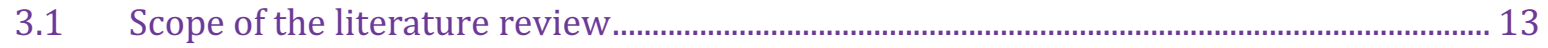

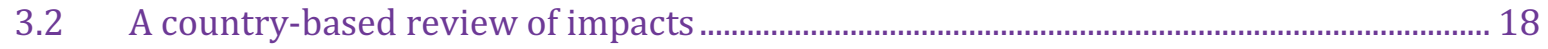

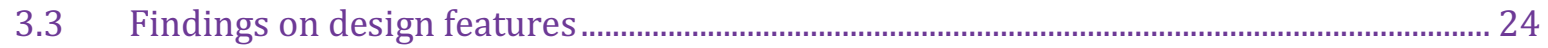

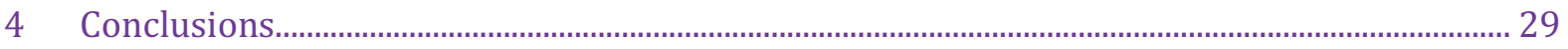

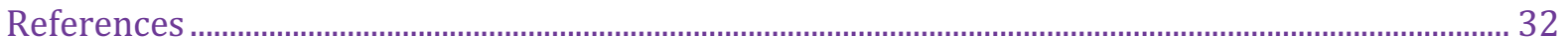

\section{Table of Figures}

Figure 1: Volume of tax incentives for R\&D and direct government funding for business R\&D 2009, as a percentage of GDP

Figure 2: B.index for large firms and SMEs........................................................................................ 11

\section{List of Tables}

Table 1: An overview of econometric work on input additionality of R\&D tax incentives. 14

Table 2: An overview of econometric work on effects of R\&D tax incentives on innovation success 16

Table 3: An overview of econometric work on effects of R\&D tax incentives on productivity..... 16 


\section{Executive Summary}

Tax incentives have become a popular policy instrument to boost research and experimental development (R\&D) activities of businesses. They offer a reduction to a firm's tax burden depending on the volume, or increase, of the expenditure the firm devoted to R\&D. The popularity of this instrument arises from the fact that it is rather simple to implement through the existing system of corporate taxation, implying low additional administrative costs both at the side of authorities and firms. R\&D tax incentives do not burden the budget of research ministries (as the costs are borne by lower revenues of the Treasury), and they can easily be altered in size and scope without much change in the administration of the measure (as compared to a grant or loan programme where a doubling or halving of the measure often implies an according change in the resources to run the scheme). In addition, R\&D tax incentives are neutral in terms of the content of R\&D activity being supported, and they reach out to all types of firms, including small firms and service firms. When run on a long-term legal base, this instrument provides a reliable base for financial planning and R\&D decisions of companies.

R\&D tax incentives offer a wide range of design features to policy makers that allow a flexible use for different policy objectives. They can be targeted to specific types of R\&D activities (including innovation activities other than scientific research), they can be varied by firm size, region or sector, and they can be applied differently to different types of R\&D expenditures. By using carry-forward or cash refund options, R\&D tax incentives can be effective also for firms with no payable taxes in a certain fiscal year. Depending on the system of corporate taxation, tax incentives may be designed either as an allowance or a credit, though one could also choose other taxes such as withholding tax on wages in the Netherlands. In recent years, some Governments have expanded tax incentives to income from intellectual property generated by R\&D (the so-called "patent box").

They main disadvantage of the measure is potentially very high costs for the Government, the extent of the costs being difficult to determine in advance. This is particularly true for volumebased tax incentives that offer tax reduction for any amount of R\&D spending. Governments can limit these costs by opting for an incremental tax incentive that provides tax reduction only for the amount of R\&D expenditure that exceeds a certain baseline. Another way to limit costs is to apply a cap per company.

$R \& D$ tax incentives have been used by many Governments for a long period of time, providing a wide empirical base for evaluating the effectiveness of this instrument. This report summarises the findings of more than 20 econometric studies on the effectiveness of R\&D tax incentives, covering programmes in 12 countries from the 1970s to the 2000s. Most studies look at input additionality, i.e. the change in business $R \& D$ expenditure resulting from R\&D tax incentives. Most evaluations find a significant input additionality in the short run. The magnitude of positive input effects varies a lot, depending on the country, the period considered and the econometric method applied. Positive effects are found for different types of R\&D tax incentives, including both volume-based and incremental schemes as well as for tax credits and tax allowances. One may conclude that $R \& D$ tax incentives are a useful tool to stimulate private $R \& D$ and raise the level of business $R \& D$ expenditure to a higher level.

With respect to design features of R\&D tax incentives, volume-based incentives and tax credits tend to produce higher additionality, as holds for more generous schemes. Incremental schemes 
turn out to be little effective in situations when the market environment for additional R\&D activities is unfavourable, e.g. during recessions. The higher positive effects of volume-based and more generous schemes have to be balanced against their higher costs. The net welfare effects of R\&D tax incentive have not been studied extensively, however. A recent longitudinal study on the welfare effects of a volume-based tax credit programme in the Netherlands suggests that input additionality diminishes over time, and that crowding out of private R\&D can only be avoided for small firms while for large firms the scheme turned out to be ineffective. This finding would suggest to differentiating R\&D tax incentives by firm size or the volume of R\&D expenditure, e.g. through introducing caps or applying different rates for small and larger firms. In addition, a tax incentive could be lowered for firms that have used the credit for some time.

While increasing the volume of R\&D activities is the primary objective of R\&D tax incentives, Governments also often expect impacts on the competitiveness of their industry, and regard fiscal incentives as a tool to improve the international attractiveness of their country as a location for innovation. Evaluations of output additionality of tax incentives are rather scarce, however. Among the few studies on the effects of R\&D tax incentives on innovation success and firm performance some find positive effects on a firm's probability to introduce new products and new processes. At the same time, there is no clear evidence on the firm level that using an $R \& D$ tax incentive raises productivity or other measures of firm performance. This result may indicate that $R \& D$ tax incentives stimulate $R \& D$ projects with a lower marginal rate of return so that productivity impacts of these projects are minor.

Despite a growing number of sophisticated and reliable studies on the impacts of R\&D tax incentives, our knowledge about the effectiveness of R\&D tax incentives and how a scheme should be designed to maximise its impacts remains limited. Most studies refer to programme effects that emerged in the 1980s and 1990s when tax incentives had been introduced rather recently and were run by a small number of countries only. Little is known about the effects of recently introduced or redesigned fiscal incentive schemes, which often show different design features compared to older programmes. In addition, most empirical studies use data from the manufacturing sector while analyses on the impacts for service firms are rare. In order to draw more reliable conclusions on the role of design features, more cross-country comparisons would be needed. Furthermore, existing results seem to be sensitive to the empirical approach used, the variation in results for the same country can be quite significant. What is more, very little is known about the interaction between $R \& D$ tax incentives and direct subsidies for R\&D. Linking administrative data from R\&D tax claims and data on direct Government subsidies for R\&D on a firm level would provide a useful base for future research along this vein. 


\section{Introduction}

Offering fiscal incentives to stimulate business research and development (R\&D) has emerged as an increasingly popular policy tool over the past decade. In 2011, 26 countries belonging to the Organisation for Economic Cooperation and Development (OECD) provided tax incentives to support business R\&D, up from 18 in 2004 and 12 in 1995 (OECD, 2011a). Business R\&D tax incentives are also offered by non-OECD countries, including Brazil, China, India, Russia, Singapore and South Africa.

R\&D tax incentives allow a firm to reduce its tax burden (or other types of mandatory contributions imposed by law such as social security contributions) depending on the size of or increase in - eligible R\&D activities. Tax incentives lower the costs of private R\&D, though they are delivered only after the R\&D activity has been performed. Tax incentives are an indirect means of supporting $R \& D$, in contrast to the direct government funding of business $R \& D$ through grants or contracts. The volume of government funding through R\&D tax incentives is significant and can reach a similar magnitude as direct R\&D funding (see Figure 1). In several countries, such as Australia, Austria, Belgium, Canada, Denmark, France, Ireland, Japan, Korea and the Netherlands, indirect support through tax incentives exceeds direct funding. 
Figure 1: Volume of tax incentives for R\&D and direct government funding for business R\&D 2009, as a percentage of GDP ${ }^{1}$

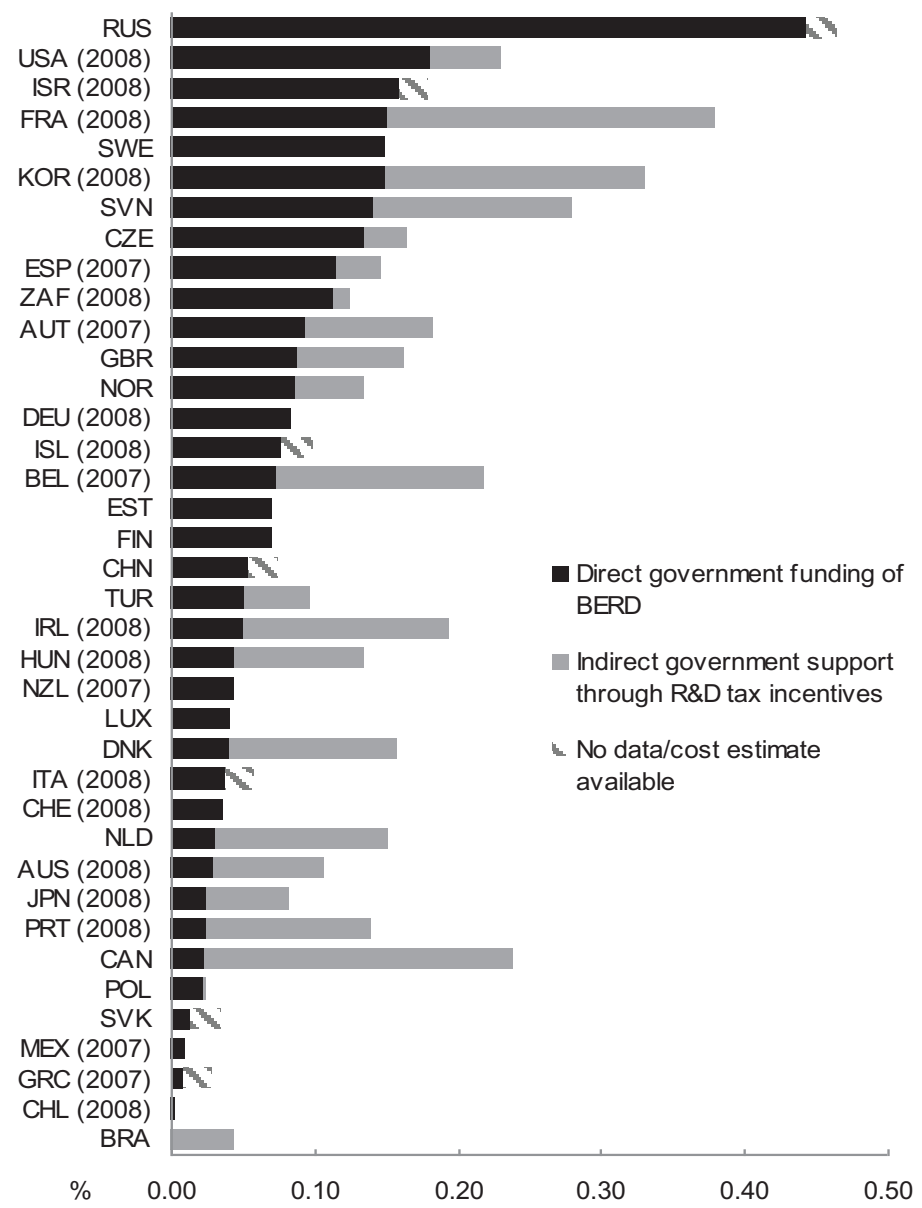

This report reviews the experience of business R\&D tax incentives in OECD countries and presents findings on using this instrument for achieving certain R\&D policy objectives. We begin by discussing the rationales for R\&D tax incentives - complementing the classical economic view with a broader political science perspective on public intervention. Since R\&D tax incentives differ considerably depending on their exact design and operation, we highlight features that contribute to the flexibility of this instrument and its ability to address varied policy objectives (Section 2).

Evaluations of R\&D fiscal incentives have been undertaken in multiple countries. We summarise (Section 3) the findings of these evaluation studies. Most of these studies focus on input additionality - the contribution of the tax incentive to increased business R\&D expenditure. There is less evidence on output additionality - the effects of R\&D tax incentives on innovation and economic impact. No study has yet tackled behavioral additionality, including whether there are lasting structural changes in enterprise innovation practices. We link the evaluation results to features of the evaluated instruments to derive conclusions about how R\&D tax incentives can be designed for meeting particular policy goals.

1 Source: OECD (2011b), p.148 


\section{Conceptual Background}

\subsection{Rationale}

The principal economic rationale for business R\&D tax incentives - as for any government support of private R\&D - is the presence of knowledge spillovers. The producers of new knowledge cannot completely prevent others from using this knowledge due to the public goods characteristics of knowledge. Hence, they cannot fully appropriate the returns on their R\&D investment. R\&D tax incentives seek to compensate for knowledge spillovers and should stimulate firms to invest more into R\&D than they would have done otherwise. A key objective of business R\&D tax incentives is thus to increase business R\&D expenditure in an economy. Less priority is given to output additionality through innovation or change in the method or thematic content of R\&D. Nonetheless, R\&D tax incentives can also be used for such policy objectives (see section 2.2).

In addition to this classical rationale, OECD (2011a) highlights other policy justifications for public support of private $R \& D$. R\&D is often a crucial investment for long-term growth and national competitiveness. Yet, R\&D investment outcomes are uncertain and difficult to assess by financial institutions due to information asymmetries. As a result, obtaining external bank funding for R\&D can be difficult and R\&D performing firms may be credit constrained.

Market failure arguments are generally used to justify public intervention. However, they are weaker in explaining government reasons for adopting particular instruments. For this, we turn to a complementary explanation rooted in political science. Bozeman and Dietz (2001) suggests that public intervention is justified by three paradigms: the market failure paradigm, the mission-oriented paradigm and the cooperation paradigm. In focusing on market failure arguments, many analyses overlook the critical importance of the mission-oriented paradigm. Governments sponsor multiple missions in such areas as defence and security, communications, or health care. Each of these missions requires products, services and systems which are underwritten by research and development. In the US, according to Bozeman and Dietz (2001), mission-oriented research comprises about nine-tenths of direct federal expenses for R\&D (and around three-quarters after including fiscal incentives). After World War II, many missionoriented public R\&D organisations were created including in construction, transport, and telecommunications, with defence establishments progressively amalgamated under similar structures. More recently, these organisations have been privatised in many countries, as have other public service providers (from water and energy through telecommunications). However, the time needed for new product and system development remains beyond the normal R\&D time horizon of most private firms. Multiple mechanisms have been thus deployed for coping for this 'time failure', from the most classical ones (public programmes) to favourable pricing mechanisms (in the pharmaceutical industry). Fiscal incentives have been used from time to time to address these issues.

The cooperation paradigm corresponds to the renewed understanding of innovation processes. 'Open innovation' simply states that firms cannot find all inputs that are needed for developing innovations within their own boundaries. Collaborations with suppliers and knowledge providers thus become essential, and are increasingly embedded in the institutional landscape. Policy supports collaborations by strengthening the links between industry and public research through numerous ways, mostly pushing universities to appropriate and transfer their 
knowledge (via technology transfer organisations) and to develop a favourable environment for spin-offs and start-up firms (through incubators, science parks and the like). On the firm side, subsidies for co-operative R\&D activities and for R\&D facilities that bring together researchers from business and academia are frequently used. Fiscal incentives such as extra-deductions on expenses for contract research with public research or, in a few cases, with small and mediumsized enterprises (mostly young firms) are another. Here fiscal policies are mobilised to support a structural change in the national innovation system.

By considering these paradigms, government intervention in favour of private R\&D should not only be evaluated against input additionality (i.e. increase in R\&D expenditure). Changing the behaviour of actors in terms of the thematic content of research and the way R\&D activities are organised is a further policy objective that needs to be considered when assessing the effectiveness of policy programmes, including fiscal incentives. Though 'behavioural additionality' of policy instruments may be even more important than input additionality in the long run (as it may propel more fundamental changes in innovation systems), behavioural additionality is more difficult to measure, and it is far more complex to identify the contribution of a certain instruments to this dimension of policy impact.

\subsection{Design features}

When implementing a business R\&D tax incentive, governments have to choose the particular characteristics of the measure. Design features include the tax on which the incentive is based, what R\&D expenditures qualify for a tax reduction (total volume of increase over a reference base; all categories of R\&D expenditure or only intramural/extramural/personnel expenses; exact definition of $R \& D$ ), the target group of beneficiaries, and whether unused claims can be carried over or refunded in cash. This section discusses the choices governments can make when designing an $R \& D$ tax incentive that supports business $R \& D$.

(i) The first choice relates to the type of R\&D tax incentive. Currently, four types of $R \& D$ tax incentives are applied: ${ }^{2}$

- Accelerated depreciation schemes for investments (machinery, equipment, buildings, intangibles) used for R\&D activities. This has been for instance the case of Italy, which was one of the first to start such a scheme.

- Special R\&D allowances enable firms to deduct more than 100 per cent of their current eligible R\&D expenditures from their taxable income. This is the case for the UK where two levels of deduction are offered: 130\% for firms in general, and 175\% for SME (2009 figures).

- Special exemptions of wage and/or social taxes for employees in R\&D activities. The Dutch scheme WBSO allows the deduction of R\&D labour costs only (for a more detailed explanation, see van Pottelsberghe et al. 2003).

2 Another type of preferential treatment of $R \& D$ activities in taxation are reductions in income taxes for R\&D workers from abroad which are used to attract key personnel from foreign countries. Some countries (e. g. The Netherlands) apply such a scheme (see OECD 2011a). 
- Tax credits allow firms to directly deduct a specific share of their R\&D expenses from the corporate tax liabilities. This type of R\&D tax incentive is currently the most widespread.

A further type of fiscal support to $R \& D$ that is closely related to $R \& D$ tax incentives is the socalled Patent Box. A patent box grants a lower corporate tax rate on profits generated from patents that are held in a certain country. Since patents are typically the result of R\&D activities, the lower tax rates represents a preferential treatment of $R \& D$ investment over other investment. A patent box was first introduced by the governments of the Netherlands and Belgium in 2007, followed by Spain and Luxembourg in 2008.

Governments may combine different types of fiscal incentives. Austria, for example, offered both an R\&D allowance and an R\&D tax credit, but repealed the allowance in 2011.

(ii) For R\&D tax credits, a central choice is to select the basis of calculation, either volume-based or incremental. A volume-based scheme allows the deduction for all eligible R\&D expenditure in a given year. In contrast, an incremental scheme allows the deduction only of the increase in R\&D expenditure during the fiscal year.

The latter was the initial choice made by numerous countries. The central argument was that public support is an incentive for doing more effort, rather than a recurrent support for doing $\mathrm{R} \& \mathrm{D}$, whatever amount.

Such a choice had one further critical fiscal advantage: it was easier over time to identify fraud. One should not underestimate the importance of ease of verification by tax authorities in designing incentive schemes. In the debates of the early 1980s, this issue was central. For instance, France and Germany shared preparatory studies before the introduction their schemes. It was anticipated that $30 \%$ of firms would initially over-value their R\&D efforts. The German Minister judged that this was an unbearably high percentage in the short term. The French Minister focused on the $70 \%$ of truthful beneficiaries, and the fact that, with a system based upon increase and not volume, it was not sustainable over the long-term to over- or under-estimate expenditures.

However this approach was considered too complex for SME, and, in a period of uncertainty, it gave rise to strong yearly variations that do not help firms to plan. This is why most systems have progressively, over a period of time, moved toward volume-based solutions.

(iii) Another important choice is the definition of eligible operations for tax deductions. The definition of R\&D differs among countries ( $\underline{\text { OECD }, 2010)}$ and can be more or less generous. A relatively narrow definition, for instance, is to qualify all expenditures on wages related to R\&D as eligible $R \& D$ expenses, and thus the tax credit becomes an incentive for investment in human capital (e.g. the Netherlands). More generous approaches add to the eligible R\&D expenditure other current costs (e.g. the UK) and depreciation on capital R\&D expenditure (including an option for accelerated depreciation, e.g. Australia).

The debate on the definition of $R \& D$ developed along two dimensions. The first dimension relates to the harmonization of definitions in order to minimise 'fiscal uncertainty' (that is the interpretation of R\&D by fiscal authorities). The current trend is to move towards an internationally accepted definition, already practiced by firms when they answer statistical offices. The main reference is the OECD's Frascati Manual (OECD, 2002). However, some 
countries have chosen wider definitions in order to support specific sectors or types of research (e.g. Belgium for green technology or China for high tech industries). But the central debate is about the connection between R\&D and innovation. A few countries have for instance included the acquisition of intangibles (patents, licenses, designs etc.) in their definition (e.g. Spain). More recently, some firms have argued that the Oslo manual would be a better reference. Fiscal specialists have tended to oppose this position because of the loose definition provided by the Oslo Manual (OECD and Eurostat, 2005) and the difficulty to identify and measure corresponding expenses. One direction that has been put forward by a number of firms is to make use of the classifications used by a number of agencies (the DoD and NASA in the US, ESA in Europe) of nine 'technology readiness levels' or TRL. The firms promoting this view (mostly in the aeronautics sector) suggest enlarging the Frascati definition to include tax incentives for TRL 6 and 7, which deal with technology demonstrations up to an operational level.

The second central, though often low-key, issue lies in the calculation of overheads. A number of systems have chosen the simple solution of a given percentage of all the direct costs accepted. The generosity of the tax incentive scheme largely depends on the latter. For instance it has been calculated in the French case that moving the percentage from $75 \%$, its present level, to $45 \%$ would represent a reduction of the tax credit by over $10 \%$.

(iv) The generosity of the tax credit is a design element that largely determines the cost of the measure. Two elements determine the generosity, the percentage of R\&D expenditure that can be deducted and the maximum amount of tax reduction that can be claimed. In addition, a tax incentive system may differentiate the level of generosity by type of firm, R\&D activities, technologies, regions or sectors.

For R\&D tax credits and deductions of other mandatory contributions the first element refers to the percentage of $R \& D$ expenditure that can be deduced from the tax burden or contribution. This percentage differs widely between countries, from $10 \%$ in Italy, $18 \%$ in the Netherlands, $20 \%$ in Canada and Korea up to 30\% in Spain and France. For R\&D tax allowances, governments have to determine the multiplier for R\&D expenditures that can be deducted from the taxable income (e.g. $130 \%$ for firms in the UK).

The second component deals with the maximum amount of tax reduction that can be claimed within one year. The level of the 'cap' selected is a central issue when evaluating tax credits (e.g. Norway, see below).

Both dimensions can be linked through thresholds. While in most cases, only the amount below the threshold can be taken into account by one firm, in some countries the threshold means a change in the percentage considered. A typical example of such a combination is France: the percentage is $30 \%$ below $€ 100 \mathrm{~m}(£ 84 \mathrm{~m})$ and $5 \%$ above. A simulation made showed that moving the cap can have important consequences: in the above mentioned case, moving it down to $€ 30 \mathrm{~m}(£ 25 \mathrm{~m}$ ) would impact only 40 large companies but would represent a $16 \%$ reduction of the total cost for public authorities in $2009^{3}$. 
In order to compare the generosity of $\mathrm{R} \& \mathrm{D}$ tax incentives, a so-called B-index has been established (figure 2). The index shows the share of R\&D tax incentives that can be deduced through an R\&D tax incentive. ${ }^{4}$ There is a wide variation in the generosity of R\&D tax incentives within the EU. While Germany, Finland and Sweden do not offer R\&D tax incentives, France and Spain do run quite generous schemes. Only few countries offer significantly higher incentives for SMEs (Canada, the Netherlands, the UK and Japan).

Figure 2: B.index for large firms and SMEs

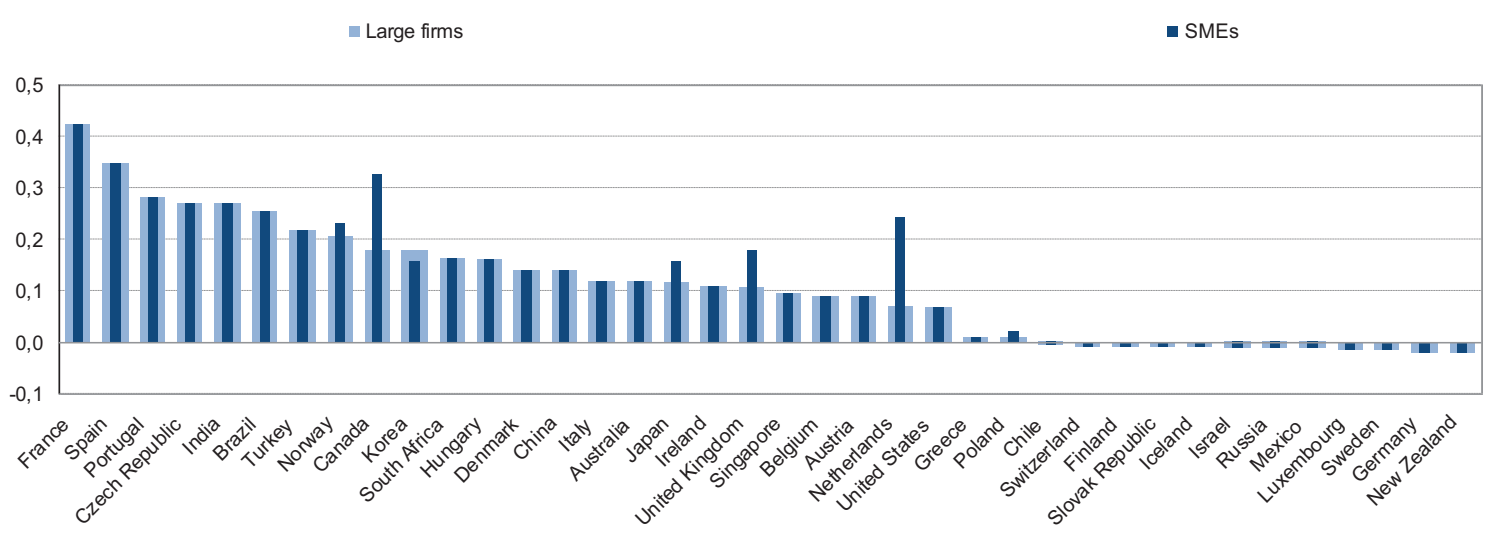

Source: OECD (2009).

(v) The definition of the subjects that are entitled to claim R\&D tax incentives is another design element. While one approach focuses on legal entities, other approaches apply the concept of 'enterprise group', based on majority ownership or on 'fiscal integration' (a feature which enables groups to balance the different results of their subsidiaries). In this case, considering only legal entities might entail a vast increase of the group amount below the cap (to take again the French situation, the Parliamentary report estimated that levels of deduction can vary for one group up to $300 \%$ taking into account different definitions).

Beyond the general lines that apply to all, many schemes tend to differentiate beneficiaries. They may be more generous for SMEs (which required the country to define what is meant by an SME) as in Canada, Japan, Norway, the Netherlands and the UK. They may be more generous for recently created firms (as in the French case where the percentage deduced is higher during the first two years).

The tax credit can also privilege certain aspects of R\&D activities. It can boost high-level employment by giving a higher reduction for the salary of recently recruited doctoral holders (French case). However the most common feature is to give a higher reduction to all expenses paid to public research and in particular universities. Such a device that supports industryuniversity collaboration then participates in fostering the linkages within the national innovation system. One could imagine other uses, such as fostering collaborations by firms with SME (though no such case has been yet identified). 
Addressing specific sectors (e.g. sectors that are considered of strategic importance by the Government or that face economic challenges) through R\&D tax incentives is difficult since most fiscal laws require very clear cut and transversal discriminations (like age or size) while a sector is less easy to delineate. EU competition law also restricts the use of R\&D tax incentives for supporting specific sectors. One solution is to identify a type of R\&D activity that is specific to a set of firms that mostly belong to the sector targeted. Some countries have chosen to target specific fields of R\&D (such as biotechnology or nanotechnology) or types of technologies (such as green technologies, cf. Belgium). Under such a design, the conditions under which a $R \& D$ tax incentive may become complex, give room for interpretation both by firms and fiscal authorities and will impose significant compliance costs for both parties.

A final differentiation is geographical: China for instance targets specific regions or development zones. The Italian government targets some southern regions. In federal countries where regional authorities have fiscal power, the latter can establish state or provincial R\&D tax credits, as is the case in about 40 US states (the tax credit is based on state taxes otherwise payable, not federal taxes).

(vi) A further design element concerns the consumption of tax credits by firms. Policy makers can choose whether tax credits apply only for firms that make profit in the same fiscal year the R\&D expense took place or whether claims can be carried backward or forward, or whether claims can be disbursed in case a firm records a loss. Governments can design R\&D tax incentives in a way that they particularly address recession periods when cash flows of firms tend to fall sharply. The French government, for example, responded to the 2008/09 crisis by making all tax credits accumulated by firms (which were until then paid over a period of 4 years) available within 2009, providing a significant boost to the cash situation of many firms.

(vii) Another dimension deals with the duration of the measure itself. In most countries these fiscal decisions are taken for a limited duration (often 4 to 5 years) and need thus to be renewed periodically. It is striking to note that very few countries have abandoned the principle once they adopted it. However the trend has been, while keeping the principle, to periodically change its conditions of operation (often for other reasons than R\&D issues). This has then been a lasting requirement by industry to ask for longer time frames for such measures to be efficient. A recent article by Arque-Castells \& Mohnen (2011) opens another alley: looking at behavioural change in Spain, they argue that a permanent system that would support 'entry into R\&D' by firms might be a very effective option, but this would require a high though transitory incentive. Ways of implementing such an approach still remain to invent.

\subsection{Fiscal incentives as complex multi-objectives policy instruments}

The scope of a fiscal incentive, and in particular a tax credit, is largely linked to its implementation features. The latter does not only promote one objective - enable firms to undertake more R\&D activities - even if it remains clearly the central one. It is a flexible instrument that can foster the connectivity within a national innovation system (e.g. work with universities), that can be targeted on certain dimensions of the R\&D activities (such as recruiting doctorate holders, or more widely supporting investment in human capital), that can support young and/or smaller firms in investing more in R\&D. This richness may explain why a growing number of Governments have mobilised it to foster a more 'innovation friendly 
ecology' in their country OECD (2011a), through a survey it conducted in 2010 among its member states, has highlighted the variety of approaches to R\&D tax incentives..

\section{Effectiveness of R\&D tax incentives: findings from evaluation studies}

R\&D tax incentives have been widely applied by governments over the past 40 years, and a large number of empirical studies analysed their effectiveness. Since R\&D tax incentive schemes tend to be rather similar across countries compared to other innovation policy measures, the situation for international policy comparison is quite favourable. A critical issue for policy learning is the role of various design features of $R \& D$ tax incentives for the tax incentive's effectiveness. Most empirical studies do not provide much insight on this issue, however, since they focus on one specific tax incentive scheme and are not able to compare different designs. Though one may compare the effects found for different types of R\&D incentives in different countries, comparability is limited since one cannot control for country or time specific effects.

This section summarises the empirical findings on the effectiveness of $R \& D$ tax incentives. The section starts with some notes on the scope of R\&D tax incentive evaluations and their methodological challenges and limitations. We proceed with a brief discussion of the results of about 20 evaluation studies conducted between the early 1990s and 2011 in different countries. Tax incentives are typically implemented at the national level as part of national taxation laws, ${ }^{5}$ consequently evaluation results refer to the effects of tax incentives under the specific legislative situation in that country. In addition, we relate the evaluation findings to the design features of the R\&D tax incentives under consideration in order to allow conclusions on the effectiveness of different policy designs.

\subsection{Scope of the literature review}

\subsubsection{Studies on input additionality}

The literature review focuses on studies that econometrically analyse the impact of $R \& D$ tax incentives on key policy goals of the instrument. Since a primary goal of R\&D tax incentives is to raise $R \& D$ spending by enterprises, most studies look at input additionality, i.e. the change in private $R \& D$ expenditure that can be attributed to the tax incentive. Table 1 lists the most important studies consulted for this review. Some of these studies were official evaluations commissioned by Governments and conducted as part of policy implementation and monitoring activities while others originated from academic work based on publically available or dedicated survey data.

The studies are typically based on firm-level panel data and either cover periods before and after the introduction of a tax incentive, or they analyse the effects of changes in the generosity of R\&D tax incentives. Methodologically, they estimate R\&D demand equations using a dummy variable for the tax credit or R\&D price elasticity (see Hall and van Reenen 2000). In recent years, control group approaches have been used too (see Corchuelo and Martinez-Ros 2009, Czarnitzki et al. 2011, Duguet 2010) that compare firms that use an R\&D tax incentive with R\&D active firms that refrain from doing so..

$5 \quad$ Regional R\&D tax incentives are available in the USA and Canada. 
Table 1: An overview of econometric work on input additionality of R\&D tax incentives

\begin{tabular}{|c|c|c|c|c|c|c|}
\hline Study & Country & Period & Industries & Method & $\begin{array}{l}\text { R\&D } \\
\text { price } \\
\text { elasticity }\end{array}$ & $\begin{array}{l}\text { Input } \\
\text { Additionality } \\
6\end{array}$ \\
\hline$\frac{\text { Berger }}{(1993)}$ & USA & $\begin{array}{l}1975- \\
1988\end{array}$ & $\begin{array}{l}\text { Manufacturing } \\
\text { (publicly listed } \\
\text { enterprises only) }\end{array}$ & $\begin{array}{l}\text { R\&D demand estimation } \\
\text { with tax credit shift } \\
\text { parameter (pooled OLS } \\
\text { with fixed effects) }\end{array}$ & 1.0 to 1.5 & US-\$ 1.74 \\
\hline $\begin{array}{l}\text { Bloom, } \\
\text { Griffith und } \\
\text { Van Reenen } \\
\text { (2002) }\end{array}$ & $\begin{array}{l}8 \text { OECD - } \\
\text { Countries } \\
\text { (Canada, } \\
\text { Italy, } \\
\text { Spain, } \\
\text { USA, UK, } \\
\text { Germany, } \\
\text { France, } \\
\text { Japan) }\end{array}$ & $\begin{array}{l}1979- \\
1997\end{array}$ & Manufacturing & $\begin{array}{l}\text { Estimation of R\&D price } \\
\text { elasticities using } \\
\text { dynamic panel models } \\
\text { (OLS, Instrument vari- } \\
\text { ables) }\end{array}$ & $\begin{array}{l}0.16 \text { to } \\
1.1\end{array}$ & / \\
\hline $\begin{array}{l}\frac{\text { Dagenais, }}{\text { Mohnen }} \\
\frac{\text { Thierrien }}{1 \text { (1997) }} \\
\end{array}$ & Canada & $\begin{array}{l}1975- \\
1992\end{array}$ & $\begin{array}{l}\text { Manufacturing and } \\
\text { Services (publicly } \\
\text { listed enterprises } \\
\text { only) }\end{array}$ & $\begin{array}{l}\text { Estimation of R\&D price } \\
\text { elasticities (Generalised } \\
\text { tobit model with ran- } \\
\text { dom and fixed effects) }\end{array}$ & 0.40 & CA\$ 0.98 \\
\hline$\frac{\text { Duguet }}{(2010)}$ & France & $\begin{array}{l}1993- \\
2003^{7}\end{array}$ & $\begin{array}{l}\text { Manufacturing and } \\
\text { Services }\end{array}$ & $\begin{array}{l}\text { Matching, i. e. } \\
\text { comparison of tax credit } \\
\text { users and non-users }\end{array}$ & / & $€ 2.33$ \\
\hline $\begin{array}{l}\text { Hægeland } \\
\text { and Møen } \\
\text { (2007) }\end{array}$ & Norway & $\begin{array}{l}1993- \\
2005\end{array}$ & $\begin{array}{l}\text { Manufacturing and } \\
\text { Services }\end{array}$ & $\begin{array}{l}\text { R\&D demand estimation } \\
\text { with tax credit shift } \\
\text { parameter (Panel-mo- } \\
\text { dels) }\end{array}$ & / & NOK 1.3 to 2.9 \\
\hline Hall (1993) & USA & $\begin{array}{l}1981- \\
1991\end{array}$ & $\begin{array}{l}\text { Manufacturing (pu- } \\
\text { blicly listed enter- } \\
\text { prises only) }\end{array}$ & $\begin{array}{l}\text { Estimation of R\&D price } \\
\text { elasticities (Generalised } \\
\text { method of moments) }\end{array}$ & 1.0 to 1.5 & US-\$ 2.00 \\
\hline$\frac{\text { Hines }}{(1993)}$ & USA & $\begin{array}{l}1984- \\
1989\end{array}$ & $\begin{array}{l}\text { Manufacturing (pu- } \\
\text { blicly listed enter- } \\
\text { prises only) }\end{array}$ & $\begin{array}{l}\text { Estimation of R\&D price } \\
\text { elasticities (pooled OLS, } \\
\text { Instrument variables) }\end{array}$ & 1.2 to 1.6 & $\begin{array}{l}\text { US-\$ } 1.30 \text { to } \\
2.00\end{array}$ \\
\hline $\begin{array}{l}\text { Klassen, } \\
\text { Pittmann, } \\
\underline{\text { Reed }} \\
(2004)\end{array}$ & $\begin{array}{l}\text { USA, } \\
\text { Canada }\end{array}$ & $\begin{array}{l}1991- \\
1997\end{array}$ & & & & $\begin{array}{l}\text { CA-\$1.3 } \\
\text { (Canada); US- } \\
\$ 3.0 \text { (USA) }\end{array}$ \\
\hline $\begin{array}{l}\text { Lokshin } \\
\text { and } \\
\text { Mohnen } \\
\text { (2012) }\end{array}$ & $\begin{array}{l}\text { The } \\
\text { Netherlan } \\
\text { ds }\end{array}$ & $\begin{array}{l}1996- \\
2004\end{array}$ & $\begin{array}{l}\text { Manufacturing and } \\
\text { Services }\end{array}$ & $\begin{array}{l}\text { Estimation of R\&D price } \\
\text { elasticities using dyna- } \\
\text { mic panel models (Error } \\
\text { correction model, } \\
\text { Partial adjustment mo- } \\
\text { del) }\end{array}$ & $\begin{array}{l}0.57 \text { to } \\
1.1 \\
\text { (small } \\
\text { enter- } \\
\text { prises). } \\
0.15-0.25 \\
\text { (large en- } \\
\text { terprises } \\
\text { ) }\end{array}$ & $\begin{array}{l}€ 3.24 \text { and } \\
1.21 \text { (small } \\
\text { enterprises). } \\
€ 0.78 \text { and } \\
0.42^{8} \text { (large } \\
\text { enterprises) }\end{array}$ \\
\hline $\begin{array}{l}\text { McCutchen } \\
\text { (1993) }\end{array}$ & USA & $\begin{array}{l}1975- \\
1985\end{array}$ & $\begin{array}{l}\text { Pharmaceutical } \\
\text { Industry }\end{array}$ & $\begin{array}{l}\text { R\&D demand estimation } \\
\text { with tax credit shift } \\
\text { parameter (Pooled OLS) }\end{array}$ & 0.28 & $\begin{array}{l}\text { US-\$ } 0.29 \text { to } \\
0.35\end{array}$ \\
\hline $\begin{array}{l}\text { McKenzie } \\
\underline{\text { and }} \\
\frac{\text { Sershun }}{(2010)}\end{array}$ & $\begin{array}{l}9 \text { OECD - } \\
\text { Countries } \\
\text { (Austra- } \\
\text { lia, }\end{array}$ & $\begin{array}{l}1979- \\
1997\end{array}$ & Manufacturing & $\begin{array}{l}\text { Estimation of R\&D price } \\
\text { elasticities using dyna- } \\
\text { mic panel models (OLS, } \\
\text { Feasible GLS, Panel cor- }\end{array}$ & $\begin{array}{l}0.15 \text { to } \\
0.22 \\
\text { (short- } \\
\text { term) }\end{array}$ & / \\
\hline
\end{tabular}

6 The values refer to the effect of one forgone unit tax revenue.

7 In the covered period there were no changes to the incremental tax incentive scheme. That is, only firms with increasing R\&D expenditure were eligible for the tax relief.

8 While the first number refers to the effect one year after the termination of the R\&D tax incentive program, the second indicates the effect 15 periods after the termination of the R\&D tax incentive program and the realization of a new steady state equilibrium. 


\begin{tabular}{|c|c|c|c|c|c|c|}
\hline Study & Country & Period & Industries & Method & $\begin{array}{l}\text { R\&D } \\
\text { price } \\
\text { elasticity }\end{array}$ & $\begin{array}{l}\text { Input } \\
\text { Additionality } \\
6\end{array}$ \\
\hline & $\begin{array}{l}\text { Canada, } \\
\text { Italy, } \\
\text { Spain, } \\
\text { USA, UK, } \\
\text { Germany, } \\
\text { France, } \\
\text { Japan) }\end{array}$ & & & $\begin{array}{l}\text { rected standard errors, } \\
\text { Arellano-Bond) }\end{array}$ & $\begin{array}{l}0.46 \text { to } \\
0.77 \\
\text { (long } \\
\text { term) }\end{array}$ & \\
\hline $\begin{array}{l}\text { Mairesse } \\
\text { and Mulkay } \\
(2004)\end{array}$ & France & $\begin{array}{l}1970- \\
1997\end{array}$ & & & & FF 2.0 to 3.5 \\
\hline $\begin{array}{l}\text { Poot, den } \\
\text { Hertog, } \\
\text { Grosfeld, } \\
\text { Brouwer } \\
\underline{(2003)}\end{array}$ & $\begin{array}{l}\text { The } \\
\text { Netherlan } \\
\text { ds }\end{array}$ & 1998 & $\begin{array}{l}\text { Manufacturing and } \\
\text { Services }\end{array}$ & & & NFL 1.0 \\
\hline
\end{tabular}

Limited data availability often prevents a cost-benefit analysis of R\&D tax incentives which makes it difficult to assess the overall effectiveness of the measure. One important exception is Lokshin and Mohnen (2012) who examine the benefits of the Dutch WSBO (Wet Bevordering Speur \& Ontwikkeling - the Dutch Research and Development Act) based on the volume of additional R\&D expenditures compared with the costs of the programme (i.e. loss in income from social security contributions).

\subsubsection{Studies on output additionality}

While the focus on input additionality is fully justified as a main criterion for evaluating the effectiveness of the instrument, governments increasingly use R\&D tax incentives to address further policy goals, including the support of SMEs, industry-science linkages, high-tech industries, young technology-based firms or certain fields of research. R\&D tax incentives, and particularly the new instrument 'Patent Box', are often used by Governments to increase the international attractiveness of their country for R\&D activities and to attract business R\&D from abroad.

A smaller number of evaluations have addressed the effects of R\&D tax incentives on the outputs of firms in terms of innovations, growth and productivity.

Table 2 lists three recent works on the effects of R\&D tax incentives on innovation success of firms. Cappelen et al. (2008) investigate output additionality in terms of introducing new products and processes and applying patents and find significant effects for innovations with rather low degree of novelty. Czarnitzki et al. (2011) find a positive impact of the Canadian R\&D tax credit on the frequency of new product development, the introduction of new-to-the-market products and the sales share of new products but do not find impacts on firm profitability and market share. The evaluation of the Austrian R\&D tax incentives (Falk et al., 2009a, 2009b) also looked at impacts on innovations, growth in sales and employment and found positive impacts for the probability to introduce new-to-the-market products. In addition, the evaluation compared the effects of fiscal incentives and direct subsidies for business $R \& D$ and found stronger effects for direct measures and particularly strong impacts for firms that used both types of government support. 
Table 2: An overview of econometric work on effects of R\&D tax incentives on innovation success

\begin{tabular}{|c|c|c|c|c|c|}
\hline Study & Country & Period & Industries & Method & Effects on innovation success \\
\hline $\begin{array}{l}\frac{\text { Cappelen }}{\text { et al. }} \\
\text { (2008) }\end{array}$ & Norway & $\begin{array}{l}1999- \\
2004\end{array}$ & $\begin{array}{l}\text { Manufacturing } \\
\text { and Services }\end{array}$ & $\begin{array}{l}\text { Logistic regres- } \\
\text { sions (regular } \\
\text { and conditional } \\
\text { upon innova- } \\
\text { tion success in } \\
\text { previous pe- } \\
\text { riod) }\end{array}$ & $\begin{array}{l}\text { Use of fiscal R\&D incentive } \\
\text { increases probability to intro- } \\
\text { duce new-to-the-firm products } \\
\text { and new processes. } \\
\text { No effect on probability to } \\
\text { introduce new-to-the-market } \\
\text { products and on the probability } \\
\text { to apply for a patent. }\end{array}$ \\
\hline $\begin{array}{l}\frac{\text { Czarnitzki }}{\text { et al. }} \\
\text { (2011) }\end{array}$ & Canada & 1999 & $\begin{array}{l}\text { Manufacturing } \\
\text { and Services }\end{array}$ & Matching & $\begin{array}{l}\text { Use of fiscal R\&D incentives } \\
\text { increases the number of newly } \\
\text { introduced products, the pro- } \\
\text { bability to introduce a new-to- } \\
\text { the-world and a new-to-the- } \\
\text { market-product and share of } \\
\text { sales with new products. } \\
\text { No effect on increased firm pro- } \\
\text { fitability, national and interna- } \\
\text { tional market share and } \\
\text { increased competitiveness. }\end{array}$ \\
\hline $\begin{array}{l}\frac{\text { Falk et al. }}{(2009 a ;} \\
\underline{2009 b)}\end{array}$ & Austria & $\begin{array}{l}2005- \\
2007\end{array}$ & $\begin{array}{l}\text { Manufacturing } \\
\text { and Services }\end{array}$ & Probit & $\begin{array}{l}\text { Use of fiscal R\&D incentives } \\
\text { increases probability to } \\
\text { introduce new-to-the-market } \\
\text { products. } \\
\text { No effect on probability to in- } \\
\text { troduce new-to-the-firm } \\
\text { products. }\end{array}$ \\
\hline
\end{tabular}

There are two recent econometric studies on the impact of $R \& D$ tax incentives on firm productivity. Both Cappelen et al. (2007) for the Norwegian tax credit and Colombo et al. (2011) for the Italian tax incentive scheme find no significant effects on labour productivity and total factor productivity, respectively (see Table 3).

Table 3: An overview of econometric work on effects of R\&D tax incentives on productivity

\begin{tabular}{|c|c|c|c|c|c|}
\hline Study & Country & Period & Industries & Method & $\begin{array}{l}\text { Effects on } \\
\text { productivity }\end{array}$ \\
\hline$\frac{\text { Cappe- }}{\text { len et al. }}$ & Norway & $\begin{array}{l}2002- \\
2004\end{array}$ & $\begin{array}{l}\text { Manufacturing } \\
\text { and Services }\end{array}$ & $\begin{array}{l}\text { Estimation of labour pro- } \\
\text { ductivity (Generalised } \\
\text { Least Squares, Genera- } \\
\text { lised Method of Momen- } \\
\text { ts: Arellano-Bond) }\end{array}$ & $\begin{array}{l}\text { No significant effects } \\
\text { for capital stock } \\
\text { provided by fiscal } \\
\text { R\&D incentives. }\end{array}$ \\
\hline $\begin{array}{l}\frac{\text { Colombo }}{\text { et al. }} \\
\underline{(2011)}\end{array}$ & Italy & $\begin{array}{l}1994- \\
2003\end{array}$ & $\begin{array}{l}\text { New technolo- } \\
\text { gy based firms } \\
\text { from manufac- } \\
\text { turing and ser- } \\
\text { vice sectors }\end{array}$ & $\begin{array}{l}\text { Estimation of the Total } \\
\text { Factor Productivity (Ge- } \\
\text { neralised Method of Mo- } \\
\text { ments) }\end{array}$ & $\begin{array}{l}\text { No significant effects } \\
\text { for variable } \\
\text { indicating the use of } \\
\text { fiscal R\&D incentives. }\end{array}$ \\
\hline
\end{tabular}

Behavioural additionality is rarely investigated in the context of $R \& D$ tax incentive evaluations. The main reason for this is that $R \& D$ tax incentives are first and foremost an instrument to raise 
the volume of business $\mathrm{R} \& \mathrm{D}$ expenditure and rarely address behavioural issues directly. Nevertheless, there are some studies the deal with behavioural impacts of R\&D tax incentives beyond the change in R\&D expenditures. Arque-Castells and Mohnen (2011) analysed the effect of the Spanish $R \& D$ tax credit on firms' decision to enter into $R \& D$ and to continue $R \& D$ activities irrespective of the future development of the scheme. They find that $12 \%$ of firms stepped into R\&D because of the tax credit, and $13 \%$ continued to invest into R\&D. Lasting state dependence is concentrated on low-technology sectors. This might drive to a significant shift in the understanding of permanent vs. transitory approaches to tax credits, the system being permanent but only applying a few years for individual firms. Another study on behavioural changes initiated by tax incentives is Hægeland and Møen (2007) on the Norwegian SkatteFUNN scheme. In a broader sense, the studies on innovation impacts of $R \& D$ tax incentives mentioned above also address behavioural additionality issues.

\subsubsection{Methodological limitations}

Though many studies on the effectiveness of R\&D tax incentives have been produced over the past two decades, the scope for clear policy conclusions is still limited due to methodological limitations the various studies face. Oxera (2006) provides a comprehensive summary of the methodological challenges that evaluations of R\&D tax incentives typically face:

- Causality: The direction of causality is unclear as it may be that a firm's investment choice is influenced by government policies but it is also possible that governments introduce $R \& D$ tax incentives because $R \& D$ expenditure is below a presumed optimum. This would imply that the efficiency of fiscal measures is underestimated.

- Instrumental variables: To overcome the causality concerns, a couple of studies (e. g. Hall 1993, Hines 1993, Bloom et al. 2002) apply instrumental variables which must be partially correlated with the endogenous explanatory variable but not with the error term. However it is difficult to identify such variables due to data limitations.

- High adjustment costs: Due to the fact that production factors are costly to adjust, it will take time before companies respond to the introduction or a change of R\&D tax incentives. Thus frequent changes to the $R \& D$ tax incentive scheme may reduce any

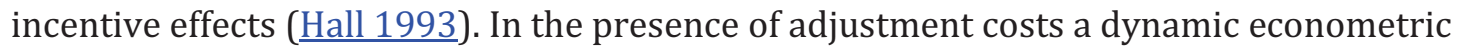
approach may be the appropriate choice to investigate the effects of R\&D tax incentives. But then it may become difficult to identify long-term effects since high adjustment costs imply a low variance of $R \& D$ expenditure on the firm level.

- Choice of control group: The effect of R\&D tax incentives will be overestimated if the dataset includes firms using the tax credit only. But even if there are non-using firms in the dataset there may be biased results due to spillovers. Either the impact of the tax incentive is overestimated if non-user benefit from spillovers from R\&D conducted by users or the impact of the tax incentive is underestimated if the performance of the nonusers declines due to the R\&D undertaken by the users (Klette et al. 2000). Another issue may arise from the non-random nature of both users and non-users which could bias the estimated coefficients upwards. Possible solutions to this problem are the use of panel data with a fixed effects approach, a difference-in-difference approach and matching estimators. But then again, these methods rely on certain assumptions which should be born in mind when interpreting the estimation results.

- Re-labelling of expenditure: A subsidy on particular activities may incentivize firms to declare activities which are carried out for other purposes as eligible activities. Such 
behaviour would lead to an overestimation of the effect caused by the R\&D tax incentive. Although Hall (1993) provides evidence that costs of the US R\&D tax incentive scheme are not significantly increased due to relabeling of expenditure it is possible that relabeling increases when firms become more familiar with the tax credit system (Eisner et al. 1984).

In order to further broaden our knowledge on the effectiveness of R\&D tax incentives, more studies on private and social welfare of this type of measure would be needed. So far, only a few studies addressed the issue of impacts on firm performance (profitability and productivity), and only one study (Lokshin and Mohnen 2012) performed a substantial cost-benefit evaluation of an R\&D tax incentive. This study profited from a rich firm-level panel data base which allowed to calculate firm-specific R\&D user costs. The empirical base for evaluation could be considerably improved if information on the use and costs of R\&D tax incentives can be merged with firm-level data on R\&D inputs, innovation outputs and firm performance (e.g. data from structural business statistics and R\&D and innovation surveys; see also Oxera 2006). Another avenue for future research concerns the link between R\&D tax incentives and direct government support for R\&D through grants. While some studies dealt with this issue (see Hægeland and Møen 2007, Corchuelo and Martínez-Ros 2009, Falk et al. 2009b), too little is yet known about interaction effects and how both types of instruments could be used effectively in parallel. Linking R\&D tax incentive data and data on direct government subsidies for R\&D on a firm level would provide a useful data base for future research along this vein.

\subsection{A country-based review of impacts}

\subsubsection{United States}

The US federal government offers an incremental R\&D tax credit program which provides a $20 \%$ deduction for eligible expenditures above a calculated base amount on tax payable. The base amount depends on whether the firm is already established or a start-up and cannot be less than $50 \%$ of a firm's current eligible R\&D expenses. Eligible costs are current $R \& D$ expenses. In case a firm does not generate profits, there are no refunds but for a period of 20 years the firm is allowed to carry the research credit forward. Recently the program was extended with a volume-based energy tax credit, i.e. a $20 \%$ deduction on all expenditures for energy research which is contracted out to public research organizations and small firms. In addition to the regular R\&D tax credit scheme there are other programs in place: the alternative incremental research credit (AIRC) and the alternative simplified credit (ASIC). Participating firms must choose between the programs.

A large body of the existing literature on the additionality effects of R\&D tax incentives is based on US data (for an overview see Hall and van Reenen 2000). These studies evaluate the effect of the research and experimentation credit which was introduced in 1981 and initially offered a firm a $25 \%$ tax credit for R\&D expenditures above the average level of R\&D expenditure carried out in the previous three years (Hines 1993). In 1986 the rate for the tax credit was reduced to $20 \%$ and remained on that level for the rest of the 1980s but other conditions to apply for the R\&D tax credit changed continuously (for a detailed overview see Table 1 in Hall 1993). The R\&D tax credit was evaluated in a couple of studies emerging during the 1990s. These studies widely differ in their estimates of additionality effects ranging from $\$ 2$ (Hall 1993) and $\$ 1.74$ (Berger 1993) to $\$ 0.29-\$ 0.35$ for US pharmaceutical firms (McCutchen 1993). In general however, the results suggest a significant impact of the tax credit increasing private $R \& D$ 
expenditure in the US by approximately $\$ 1$ per $\$ 1$ of foregone tax revenue ( $\underline{2000})$.

The costs of an R\&D tax incentive scheme can increase if firms re-label activities that previously have been not carried out for R\&D purposes. Hall (1993) cites results of a study conducted by the US Government General Accounting Office from 1989, which showed that firms tried to claim some unqualified expenditures under the credit. Yet the total amounts disallowed remained fairly small, which hints to the costs of the US R\&D tax incentive scheme not being significantly increased due to relabeling of expenditure. According to OECD (2011a), the foregone tax revenue due to the R\&D tax incentive scheme totalled $\$ 5.1 \mathrm{~b}$ ( $€ 3.2 \mathrm{~b}$ ) or $0.17 \%$ of GDP in 2005 and $\$ 7.1 \mathrm{~b}(€ 4.5 \mathrm{~b})$ or $0.18 \%$ of GDP in $2008 .{ }^{9}$

\subsubsection{Canada}

Canada established an incremental R\&D tax incentive scheme during the 1960s which was abandoned in favour of a volume based approach in the 1980s on the national level and complemented by numerous regional programs (Dagenais et al., 1997; van Pottelsberghe et al., 2003). With the SR\&ED tax credit program Canada offers a volume-based 35\% deduction for small Canadian-owned firms up to a threshold of C \$3m $(£ 1.9 \mathrm{~m})$ of R\&D expenditure and $20 \%$ beyond. Before 2008 the threshold up to which $35 \%$ were deductible was $\mathrm{C} \$ 2 \mathrm{~m}(£ 1.2 \mathrm{~m})$. Large firms can deduct $20 \%$ for its eligible R\&D expenses. The deduction is calculated from the tax payable with the option of cash refunds for small Canadian-owned firms and carry-back (3 years) as well as carry-forward (20 years) available to all firms. Eligible R\&D expenses are all current R\&D expenses as well as expenses on R\&D machinery and equipment. Since 2008 up to $10 \%$ of $R \& D$ conducted outside of Canada is eligible for the credit. The forgone tax revenues due to the R\&D tax incentive scheme equalled $\mathrm{C} \$ 2.3 \mathrm{~b}(€ 1.4 \mathrm{~b}$ ) or $0.21 \%$ of GDP in 2002 and $\mathrm{C} \$ 3.2 \mathrm{~b}$ ( $€ 2.0 \mathrm{~b}$ ) or $0.22 \%$ GDP in 2008 .

Canadian studies provide evidence on significant additionality effects of R\&D tax incentives on private R\&D expenditure. According to the results provided by Parsons and Phillips (2007), who surveyed several evaluation studies of the SR\&ED tax credit program covering a period from 1964 to 1994 , the $R \& D$ tax incentive scheme raises private $R \& D$ expenditure on average by $\mathrm{C} \$ 0.98$ per $\mathrm{C} \$ 1$ of foregone tax revenue. However, the studies cover differing periods and differing R\&D tax credit parameters.

Czarnitzki et al. (2011) use cross-section data to analyze whether the Canadian R\&D tax incentive program does have an impact on innovation output of Canadian firms. They find that firms using the R\&D tax credit more frequently develop new products and also gain a higher share of sales with new or significantly improved products. Subsidised firms also exhibit a higher likelihood to introduce new-to-the-market-products on both the world and the national market.

Parsons and Phillips (2007) estimate the costs of the Canadian R\&D tax incentive program. They cite an evaluation study by Finance Canada and Revenue Canada from 1994 which surveyed recipient firms and suggests that costs of complying with SR\&ED tax support requirements

$9 \quad$ All ccurrency conversions in this report are at prevailing exchange rates of December 2011, using Google's currency converter function. 
significantly depend on both the amount of credits requested as well as the frequency of application. For firms with ongoing applications the compliance costs totaled up to $15 \%$ of the SR\&ED credit requested if the claim was less than $\$ C 100,000$. Firms claiming between C $\$ 100,000$ - C\$500,000 ( $£ 62,000$ - $£ 310,000$ ) reported $10 \%$ compliance costs while firms which claimed more than $\mathrm{C} \$ 500,000$ reported cost of compliance of 5.5\%. Departing from these survey results, Parsons and Phillips (2007) calculate administration and compliance costs mounting to $10 \%$ of the subsidy amount.

\subsubsection{Norway}

The Norwegian approach (SkatteFUNN) is volume-based but related to R\&D projects: i. e. only enterprises with projects approved by the Norwegian Research Council are allowed to claim the tax deduction. The R\&D tax incentive scheme in Norway features a ceiling for eligible R\&D (the so-called 'cap'). The maximum allowable sum for R\&D projects conducted by the enterprise self is NOK $4 \mathrm{~m}$ per year (about $£ 0.4 \mathrm{~m}$ ). In cases where enterprises collaborate with an approved $R \& D$ institution (universities and institutes), the maximum sum is NOK $8 \mathrm{~m}(£ 0.9 \mathrm{~m})$ The existence of such a cap allows a comparison between firms investing above and below the cap. The firms investing below the cap should have an incentive to increase their R\&D spending as the subsidy would increase as well. In contrast, firms already investing above the cap would not have an incentive to increase their R\&D expenditure due to the tax incentive. As a result one would expect to observe different growth rates of R\&D expenditure in both groups. The study of Hægeland and Møen (2007) finds support for this hypothesis. They find that the Norwegian R\&D tax incentive scheme significantly increases private R\&D expenditure with additionality effects ranging from $1.3-2.9$ per foregone unit of tax revenue..

A positive effect of SkatteFUNN is also found for innovation outcomes (Cappelen et al. 2008). Firms using SkatteFUNN innovate more frequently and are more likely to successfully develop new processes as well as new-to-the-firm-products. However the likelihood to develop a newto-the-market-product or a patent is not affected by participation in SkatteFUNN. One methodical reason for this observation could be the high number of small and medium enterprises (SME) being part of the sample. Another more systemic reason could be that caps are too low compared to the high risk of failure and to possible unintended knowledge transfers attached to innovation processes aiming at the generation of genuinely new knowledge.

Since R\&D activities are one of the key determinants of productivity growth, one may expect that $R \& D$ tax incentives also accelerate productivity growth. In case of Norway this does not seem to be the case (Cappelen et al. 2007) ${ }^{10}$. Subsidized R\&D projects do not differ from other $R \& D$ projects in their productivity effect. Yet this can be due to the low number of observations for the period after SkatteFUNN was introduced. It may be the case that firms need more time to translate innovation activities into productivity enhancing new products and/or processes.

\subsubsection{The Netherlands}

The volume-based Dutch WBSO scheme reduces the wage cost of R\&D rather than the level of corporate income tax. It provides allowances on the employers' part of the wage tax and social security contributions of R\&D personnel. In 2009 the reduction encompassed $50 \%$ on the first

For all currency conversions, the current exchange rate of EUR $1=£ 0.837$ is used. 
EUR 150,000 ( $£ 125,000^{11}$ ) of the R\&D wage bill (64\% for start-ups) and 18\% beyond. In 2010 the threshold for the 50\% reduction was raised to EUR 220,000 ( $£ 184,000)$. Since 2009 there is also an income tax deduction for self-employed R\&D workers (with at least 500 hours on R\&D) of EUR 11,806 $(£ 9,865)$ with additional EUR 5,904 $(£ 4,933)$ for start-ups. Due to the high income tax levels and high social security premiums for employers and employees this approach lowers R\&D labour costs significantly (van Pottelsberghe et al. 2003). The ceiling for eligible R\&D wage bills is EUR $14 \mathrm{~m}(£ 11.7 \mathrm{~m})$. The foregone tax revenues caused by the WBSO scheme amounted to EUR $329 \mathrm{~m}(£ 275 \mathrm{~m})$ or $0.07 \%$ of GDP in 2003 and EUR $445 \mathrm{~m}(£ 372 \mathrm{~m})$ or $0.07 \%$ of GDP in 2008 respectively.

The latest evaluation of the WBSO scheme provides evidence for the approach to be inefficient (Lokshin and Mohnen 2012). While they find short-term additionality effects of EUR 3.24 for small firms (with less than 200 employees) and EUR 1.05 for large firms, and long-term additionality effects (after 15 years) of EUR 1.21 for small firms and EUR 0.42 for large firms, the estimated costs of the program seem to outweigh the benefits.

The evaluation compares the additionality effects with the fiscal revenue losses and finds that welfare losses can mount up to $85 \%$ of the foregone tax revenue since volume-based tax incentive schemes always support activities which would have been carried out anyways. Even in the presence of social returns on R\&D, which are assumed to have a magnitude of $50 \%$, net welfare losses may occur if compliance and administration costs as well as excess burden are taken into account.

\subsubsection{France}

Since 2008 the French Research tax credit (CIR) provides a volume-based reduction of $30 \%$ up to a threshold of EUR 16M ( $€ 13.4 \mathrm{~m})$ R\&D expenses which was increased in 2009 to EUR $100 \mathrm{M}$ $(£ 83.7 \mathrm{~m})$. Beyond this threshold the deduction rate is $5 \%$. Firms which claim the tax credit for the first time can deduct 50\% in the first year and $40 \%$ in the second year. Eligible expenses are all current R\&D costs and the depreciation of capital assets. The deduction is calculated from the tax payable without a maximum amount restricting the generosity of the scheme. France pursued an incremental R\&D tax incentive scheme until 2003, which was complemented in 2004 and eventually replaced in 2008 by the volume-based approach outlined above ( $\underline{\text { OECD }}$ 2011a; Duguet 2010). The foregone tax revenues due to the R\&D tax incentive scheme totalled $€$ $547 \mathrm{~m}(£ 458 \mathrm{~m})(0.03 \% \mathrm{GDP})$ in $2004, € 1.5 \mathrm{~b}(£ 1.25 \mathrm{~b})(0.08 \% \mathrm{GDP})$ in 2008 and $€ 5.6 \mathrm{~b}(£ 4.7 \mathrm{~b})$ $(0.29 \%$ GDP) in 2009.

The incremental approach which was applied until 2003 has been evaluated by Duguet (2010) with a French firm panel covering the period of 1993-2003. To identify the impact of the R\&D tax incentive scheme he matches firms using the R\&D tax credit with very similar firms not using the fiscal incentive. He finds an additionality effect of EUR 2.33 per foregone EUR tax revenue. However the additionality effect disappears, if the control group is narrowed down to $R \& D$ active firms, which do not use the R\&D tax credit. Hence there is no clear evidence of an expansive effect of the incremental R\&D tax credit scheme.

11 For all currency conversions, the current exchange rate of EUR $1=£ 0.837$ is used. 


\subsubsection{Italy}

The Italian R\&D tax credit was introduced in 2007 and offers a volume-based deduction rate of $10 \%$ for $R \& D$ expenses which can increase up to $40 \%$ if $R \& D$ is carried out together with universities or public research organisations. Eligible expenses are all current R\&D costs as well as expenses for R\&D machinery and equipment. The deduction is calculated from the tax payable up to a maximum of $€ 50 \mathrm{~m}(£ 41.9 \mathrm{~m})$ of eligible R\&D. The Italian scheme does not allow refunds or carry-over for unused credit.

Colombo et al. (2011) compare the effects of automatic and selective R\&D subsidy schemes on productivity of Italian firms. They consider R\&D tax credit as an automatic subsidy mechanism because it is available to all firms. Selective R\&D subsidy schemes on the contrary are available only to firms that decide to engage in a competitive process and submit an R\&D project to assessment and approval by an expert committee. Productivity growth is measured by growth of the total factor productivity (TFP). Using a panel of 247 new technology-based firms which are observed from 1994-2003 they find support for selective R\&D subsidy schemes to have a significantly positive effect on TFP growth. \&D tax incentives however do not exhibit a significant effect.

This is complemented by a recent study by ISTAT (Caiumi, 2011) on regional tax incentives, an initiative at the beginning of the 2000s, which targeted firms in the Southern regions. This enabled to study their R\&D behaviour before and after the initiative, and to compare recipient firms to a matched sample on other regions with similar characteristics. She concludes that there is no additionality and that at best it helps firms to overcome financial constraints. In her opinion, tax credits are not "an optimal tool for a regional policy aiming at targeting local development".

\subsubsection{Spain}

Spain introduced a R\&D tax incentive scheme which became permanent in 2009. It is a combination between several elements: a hybrid approach of both volume-based and incremental tax credit, a payroll withholding tax credit for R\&D personnel and an innovation tax credit. The R\&D tax credit provides a $25 \%$ deduction rate on the volume of current R\&D costs. The incremental tax credit is available if current $R \& D$ costs exceed the average $R \& D$ expenses of the previous two years and allows a $42 \%$ deduction on current R\&D costs. The deduction is calculated from the tax payable and can take a maximum value of $35 \%$ of tax liabilities. The firms are allowed to carry the credit forward (up to 5 years) without the option to get refunds in case the credit is not used. The payroll withholding tax credit can be applied on either R\&D wages $(17 \%$ deduction rate) or on the social contribution of newly hired researchers $(40 \%$ deduction rate). The innovation tax credit offers a deduction rate of $8 \%$ on the volume of the costs for advanced technology solutions and the acquisition of intangibles (e. g. patents and licenses).The deduction is calculated from the tax payable with a maximum value of EUR $1 \mathrm{~m}$ $(£ 0.8 \mathrm{~m})$. The foregone tax revenue due to the R\&D tax incentive scheme totalled EUR $205 \mathrm{~m}$ $(£ 171.5 \mathrm{~m})(0.02 \% \mathrm{GDP})$ in 2002 and increased to EUR 142M (£118.9m) $(0.09 \% \mathrm{GDP})$ in 2009.12 
Corchuelo and Martinez-Ros (2009) evaluate the Spanish R\&D tax incentive scheme with data covering the period from 1998 to 2002. Using a sample of manufacturing firms with more than 10 employees they apply a Matching method and find a positive and significant sample average treatment effect on the treated (ATT) which is higher for SMEs than for large firms. The sample average treatment effect on the non-treated (ATN) firms is however insignificant. When considering R\&D performers only they observe a positive and significant ATT for large firms only while the ATN is positive and significant for the full sample of firms. This indicates that $R \& D$ efforts could be increased if more firms would use the fiscal R\&D incentive scheme.

\subsubsection{Austria}

The Austrian R\&D tax incentive scheme is a hybrid approach offering both a volume-based tax allowance and a volume-based tax credit. The deduction rate for the R\&D tax credit is $8 \%$ from tax payable while the rate for the tax allowance is $125 \%$ (in contrast to the normal deduction rate of $100 \%$ ) from taxable income. Eligible R\&D expenses comprise all R\&D expenses as covered by the Frascati Manual, i. e. current, machinery and equipment as well as capital. While there is no maximum deduction for in-house $R \& D$, contracted $R \& D$ can be deducted up to a maximum amount of EUR 100,000 $(£ 83,699)$. The scheme provides the opportunity for refund within the year the expenses are incurred if the credit or the allowance cannot be used. The approach is complemented by the R\&D allowance for economically viable inventions which is available for activities resulting in patents. Compared to the tax incentive scheme however the eligible expenditures are defined significantly narrower. The foregone tax revenue due to the R\&D tax incentive scheme amounted to EUR 121M (£101.2m) (0.04\% GDP) in 2005 and increased to EUR 340m (£284.6m) (0.12\% GDP) in 2008.

Falk et al. (2009a) evaluate the Austrian R\&D tax incentive scheme and provide results on the different effects of both the direct R\&D subsidies as well as the indirect subsidies provided by the $R \& D$ tax incentive scheme. The study does not find evidence for a higher growth of R\&D expenditure neither for directly nor indirectly subsidised firms when compared to nonsubsidised R\&D performing firms. Moreover they find firms solely using R\&D tax incentives to have significantly lower growth rates in R\&D expenditure. The study also investigates the effect of R\&D subsidies on innovation output. Firms using R\&D tax incentives only exhibit a higher probability to introduce new-to-the-market products than firms not using any R\&D subsidy at all. Compared to firms which are directly subsidised, the probability is roughly equal. The highest probability is found for firms using both the $R \& D$ tax incentives and direct $R \& D$ subsidies. Considering the probability to introduce incremental innovations, i. e. new-to-thefirm-products, the study does not find a statistical difference between subsidised and nonsubsidised R\&D performers. The authors also have a look at the effect of receiving $R \& D$ subsidies on the growth of sales and employment on firm level. While they find a positive effect of receiving both types of $R \& D$ subsidies on sales growth, there is no evidence for an effect of R\&D tax incentives neither on employment growth nor on sales growth.

\subsubsection{Cross-Country Analyses}

The impact of R\&D tax incentive schemes has also been analyzed using macro data. Bloom et al. (2002) use data from nine OECD countries covering the years 1979 to 1997 . They develop a measure for user costs of R\&D, which contains estimates of real interest rates, depreciation allowances to R\&D investments, net present values of R\&D tax credits and corporate income tax rates. They estimate a model with aggregated R\&D expenditure being the dependent variable 
which is explained by user cost of R\&D, output, time and country specific effects. Using an instrumental variable approach, which is taking account of the endogeneity of the user cost of $R \& D$, the study finds a significant impact of fiscal R\&D incentives with a short-term elasticity of 0.1 and a long-term elasticity of -1.0 .

With a similar dataset McKenzie and Sershun (2010) expand this approach and also take the national tax level explicitly into account. The idea here is that a positive effect of $R \& D$ tax incentives may be countervailed by a high tax level in general. They use a dataset including eight OECD countries spanning from 1979 - 1997 and find the elasticities regarding the general tax level to be slightly higher than tax credit elasticities, which highlights the decisive role of the tax system in general for the extent of R\&D activities.

\subsection{Findings on design features}

In this section we discuss the main findings on various design features, including the definition of R\&D activities, whether to apply an incremental or a volume based incentive, the choice of the tax or contribution on which the incentive is applied, whether a credit or an allowance is used, the generosity of the incentive, the preferential treatment of specific types of firms or R\&D activities, the use of caps, carry back and carry forward rules, the option to refund unused credits, and the administrative requirements imposed on firms.

\subsubsection{Definition of R\&D activities}

When running an R\&D tax incentive, governments have to decide on the R\&D activities that should be covered by the scheme. The three major options are to consider the costs of human resources only (and there act upon social taxes), all current costs of R\&D activities, and total costs of R\&D including equipment and machinery and extramural R\&D. Referring to accounting rules (such as IFRS) is one option, however the trend seems to be adopting the Frascati manual. One could consider this movement that focuses only on R\&D as rather paradoxical at a time where the core rational for adopting such policies is to foster firm innovations capabilities and through them increased activity, employment and welfare. But an enlargement considering for instance the Oslo manual would have huge financial implications at a time of budgetary restrictions unless the measure is concentrated on a certain type of firms or a 'cap' established. On this aspect, the empirical literature does not tell much. There have been no simulations based upon the different datasets built about the effects of different definitions.

\subsubsection{Incremental or volume based incentives}

Governments have experimented with incremental and volume based R\&D tax incentives, and a combination of both, for some decades. There is hardly any pattern observable in the results of the evaluations of incremental or volume-based tax incentive schemes. The studies differ significantly in available data, observed time periods and the evaluation method applied. Though the highest input additionality can be found for incremental tax credit schemes in the USA and France, the results primarily refer to the 1970s, 1980s and 1990s when there was a general upwards trend in business $R \& D$ spending. The Japanese experience suggests that incremental tax credits are poorly effective in times when market incentives to enlarge R\&D activities are missing. Detailed implications for the policy arena are hence hard to derive.

Volume based R\&D tax incentives have become very popular throughout the world and this may be due to the lower administration and compliance costs they impose on both the firms and the 
public administration. The downside of the volume-based approach is that also R\&D expenditure is subsidised which would have been carried out anyway. Hence the costs of such a programme are quite high. Incremental schemes do not suffer from this drawback as they only subsidise incremental $R \& D$ expenditure. However, they induce significantly more administration and compliance costs. In addition, Hall and van Reenen (2000) note that incremental schemes with a moving average base like those used in Japan and the USA greatly reduce the incentive effect of the credit because of the instability associated with such an approach and the progressive narrowing of the effect when the base achieves a certain threshold.

Hence it is difficult to assess whether an incremental or a volume-based approach is favourable based on the results of the existing studies because most of them do not provide a full-scale cost benefit analysis. A notable exception is a recent study by Lokshin and Mohnen (2012), which shows that volume-based R\&D tax incentives generate a considerable welfare loss, which may mount up to $85 \%$ of the forgone tax revenue. ${ }^{13}$ These losses occur even in the presence of large social returns to R\&D if administration and compliance costs are taken into account (see below).

It is thus a policy choice whether to focus on high additionality (i.e. a substantial and sustainable increase in private R\&D expenditure) and accept an expensive policy measure, or whether to focus on potentially high welfare effects but with only limited increase in total R\&D expenditure.

\subsubsection{Corporate tax or social contribution}

Most R\&D tax incentives are applied to corporate taxation, with the important exception of the Netherlands that run an incentive scheme based on the social contributions that have to be paid for R\&D workers. While earlier evaluations of the Dutch scheme (Poot et al. 2003) found positive additionality, the above mentioned study by Lokshin and Mohnen (2012) found welfare losses. This does not imply, however, that incentives based on reducing labour costs of R\&D workers are less effective since the study by Lokshin and Mohnen has so far been the only analysis of welfare effects of $R \& D$ tax incentives. It is not implausible that welfare analysis for other volume-based tax incentive schemes will find similar results.

\subsubsection{Generosity of the tax incentive}

The size of the rate of a tax credit, or the amount of super deduction in case of a tax allowance, is a critical decision to be made by governments which largely determine the costs of the incentive scheme. Moreover the decision on the generosity of a scheme is argued to have a decisive role in attracting and retaining large R\&D players. While the results of the evaluation studies indicate that more generous schemes lead to higher R\&D efforts (see chapter 3.2), the interaction with the general tax level has to be taken into account when considering the impact of a R\&D tax incentive's generosity on business $R \& D$ expenditure. First, the cash effect of an $R \& D$ tax incentive falls with the rate of the tax on which an allowance or credit is applied (Warda 2001).

13 The welfare analysis in Lokshin and Mohnen (2012) compares scenarios with and without tax incentives in place. They relate the $R \& D$ spending that would be lost after removing the WBSO programme to the government savings over the period from the removal of the tax incentive scheme to the time where firm's R\&D stocks reach a new steady state. Note however that the sample in Lokshin and Mohnen (2012) consists of continuous R\&D performers only. Hence they do not consider additional R\&D due to the beginning of R\&D activities in their welfare analysis. 
This means that countries with low corporate tax rates need more generous R\&D tax incentives to produce similar effects compared to countries with higher tax rates. Secondly, there is some empirical evidence that lowering the general level of corporate taxation might have a similar or even higher impact of $R \& D$ investment decisions than an R\&D tax incentive. McKenzie and Sershun (2010) find for cross-country data higher elasticities of R\&D for the level of corporate taxes tax than for the size of R\&D tax incentives both in the short and the long run.

In case of volume-based tax credits, a generous fiscal incentive is likely to produce high input additionality in the first years after its start, but limited effects in the long run. One could thus argue in favour of diminishing generosity for firms that have been using a tax credit for some time, i.e. offering a higher tax reduction for firms that use the credit for the first time or in the first years. The French R\&D tax credit applies such a policy. Alternatively, one could reduce the generosity of a R\&D tax credit over time, though this would provide diminishing incentives for newly established firms to engage in $R \& D$.

A country or a region may also have an incentive to increase the generosity of the scheme to attract foreign $R \& D$ investment, i.e. a generous $R \& D$ tax incentive can make a country or a region more attractive relative to other locations. The increase in foregone tax revenues may be outweighed by the benefits in terms of employment, value added and knowledge spillovers (Criscuolo et al. 2009). Empirical results suggest that R\&D location decisions are sensitive to $R \& D$ tax incentives. However the available data does not provide sufficient information to verify a causal relationship between the introduction or a particular design feature of R\&D tax incentive schemes and the location of R\&D investments. Thus the results should be taken with care. In addition, empirical evidence mostly refers to a time when some countries did offer R\&D tax incentives while many others did not. Today, the situation has changed as most OECD countries offer some type of R\&D incentive. Noteworthy exceptions refer to countries that have a very R\&D intensive industry with a large number of highly internationalised companies that are often technology leaders in their sectors (Finland, Germany, Sweden, Switzerland). One may assume that companies from these countries did arrange with this situation and having found an effective distribution of their global R\&D activities that takes into account both the costs of R\&D and other factors such as access to skills, scientific excellence, customers and suppliers. Nevertheless, when it comes to deciding where to locate additional R\&D activities within a company that has an extensive international network of R\&D locations available, R\&D tax incentives may still have a substantial influence.

Hines (1994) reports that in 1986 when the deduction rate of the US R\&D tax credit was reduced from $25 \%$ to $20 \%$, observers predicted a relocation of R\&D activities from the US to countries abroad. Yet the net effect of the reduction was insignificant, i.e. the fraction of $R \& D$ performed abroad relative to total R\&D of US firms stayed roughly equal at around $10 \%$. Wilson (2009) however finds a positive relationship between the generosity of the R\&D tax incentive scheme and the R\&D choice of firms within the US. Using firm level data he shows that on average "a 1 percentage point increase in a state's effective R\&D credit rate leads in the long run to a $3 \%-4 \%$ increase in R\&D spending within the state and a 3\%-4\% decrease in R\&D spending outside of the state, such that R\&D nationwide is essentially unchanged" (Wilson 2009, p.435). Also the study of Bloom and Griffith (2001) suggests that the choice of R\&D location is influenced by tax induced changes in the cost of R\&D. Their results indicate that domestic R\&D is negatively associated with the domestic user cost of R\&D while it is positively associated with 
foreign user cost of R\&D. They conclude that domestic and foreign R\&D are substitutes which implies that location decisions for R\&D may be influenced by R\&D tax incentives.

Still it is an open question whether fiscal incentives for R\&D have a stronger effect on firms' location decisions in countries where the overall tax burden on business is higher or lower. It can be argued that the impact of R\&D tax incentive schemes in a particular country would be greatest when these measures helped offset higher taxes in other areas. To the best of our knowledge there are no studies which evaluate the interplay between the general tax burden and R\&D tax incentives in particular. The study of McKenzie and Sershun (2010) is an exception in the sense that they consider R\&D tax incentives and effective tax rates on the marginal cost of production as independent determinants of a country's R\&D intensity. They find that both determinants are equally important but they do not include an interaction term however, which would be necessary to answer the question whether R\&D tax incentives are more effective in countries with higher or lower tax rates.

The impact of generous R\&D tax incentives should not be considered separately from other important factors as e. g. access and support to local markets which includes the proximity to both other corporate activities and local customers as well as access to local science and technology or the availability of a skilled workforce, engineers and scientists, and strong intellectual property rights (e.g. Alcacer and Chung 2007; Branstetter et al. 2006; Thursby and Thursby 2006; von Zedtwitz and Gassmann 2002; Kumar 2001). These factors may have an even stronger impact on the location decision for $R \& D$ than the existence of $R \& D$ tax incentives. Yet for R\&D location decisions of multinational firms the generosity of a particular R\&D tax incentive scheme may be a crucial determinant, given that all other determinants of their location decision are equal among competing countries. In this case it is rational for a multinational firm to decide upon the B-index provided by the OECD.

\subsubsection{Preferential treatment of SMEs/firms with low R\&D expenditure and the use of caps}

The issue of focusing R\&D tax incentives on SMEs only, or treating SMEs preferentially, is strongly linked to the question of differences in barriers to private R\&D investment by firm size. There are several arguments for higher R\&D barriers in SMEs: Since R\&D is characterised by indivisibilities, there is a minimum size of R\&D projects and SMEs face a higher share of R\&D in total firm activities (and thus higher R\&D costs per earnings resulting in more severe financing problems). As much R\&D expenditure is fixed costs, SMEs will have a higher fixed cost exposure from $R \& D$ than large firms. In case $R \& D$ activities fail to produce earnings, high fixed costs may jeopardise the whole firm. Spillovers from R\&D activities may be higher in SMEs owing to difficulties of SMEs to effectively protect their IP.

Focusing R\&D tax incentives on SMEs only will both reduce the costs of the measure and its impact on total private R\&D. The study of Lokshin and Mohnen (2012) shows that a volume based approach causes higher additionality effects for SMEs than for large firms. Based on data for the Dutch WSBO scheme, they compare two scenarios. In the first scenario the R\&D tax incentive programme is in operation while it is abandoned in the second scenario. The effects are calculated for a period of 15 years because the firms need this time span to adjust to the new steady state level of R\&D capital. Now for both scenarios the R\&D expenditure and the tax revenues are estimated. For SMEs they find that after one year the additionality effect is EUR 3.24 while it is merely EUR 0.78 for large firms. This pattern is similar after the new equilibrium has been reached. The additionality effect for SMEs is calculated to be EUR 1.21 while it drops 
for large firms to EUR 0.42. This result is supported by Hægeland and Møen (2007) who find that small firms have the highest degree of additionality when participating in the Norwegian $R \& D$ tax incentive programme. Empirical evidence suggests a higher 'value for money' when focusing on smaller firms. The issue is then whether it is the size of the firm or the size of the $R \& D$ investment that counts. This is the meaning of ceilings or 'caps' present in many systems. We have however limited knowledge about the relevant cap to employ. In Norway, for example, the cap is very low (NOK $8 \mathrm{~m}$ or $£ 0.9 \mathrm{~m}$ for cooperative R\&D projects and NOK $4 \mathrm{~m}$ or $£ 0.4 \mathrm{~m}$ for non-cooperative R\&D projects), leaving many SMEs outside of the cap , so that it is difficult to interpret the more positive results observed for firms with R\&D activities below the cap. Similarly, studies undertaken by the French Parliament show that moving the cap down from $€ 100 \mathrm{~m}(£ 84 \mathrm{~m})$ to $€ 30 \mathrm{~m}(£ 25 \mathrm{~m})$ would affect only a limited number of (larger) companies while significantly reducing costs for the government. Since additionality tends to be lower for larger firms introducing caps may only marginally affect the impact of a tax incentive on increasing R\&D expenditure in the business sector. In terms of welfare effects, the result of Lokshin and Mohnen (2012) suggest that in case of volume-based R\&D tax credits, caps may even increase the scheme's welfare performance.

\subsubsection{Privileging certain types of R\&D activities}

The best-known type is associated with 'systemic failures' and deals with industry-university collaborations (and/or the recruitment of the Human output of academic research, Doctorate holders). We have only one study analysing the impact of such support. The Norwegian approach is to grant a cap of NOK $8 \mathrm{~m}(£ 0.9 \mathrm{~m})$ for cooperative R\&D projects compared to NOK $4 \mathrm{~m}(£ 0.4 \mathrm{~m})$ for non-cooperative $R \& D$ projects. Indeed the evaluation of the programme finds positive additionality effects for firms investing below the cap on cooperative R\&D expenditure. However the magnitude of the effect is lower than compared to non-cooperative $R \& D$ expenditure and not statistically different. Moreover the cooperation with research institutions does not seem to induce higher or lower additionality effects. Also the evaluation does not find evidence that the tax incentive had a large impact on the decision to begin cooperative R\&D. The results are however to be taken with care as the control group is quite small and the available data does not allow controlling for direct R\&D grants used to finance cooperative R\&D. It thus remains to be studied further in a wider environment comparing the different types of support and their relative but also cumulative effects.

\subsubsection{Administrative and compliance costs}

Compliance costs largely depend on the system of corporate taxation and the way the tax incentive is administered and controlled by tax authorities. There are few surveys about compliance costs. The shared knowledge is that compliance costs are far more important for incremental systems than for volume-based ones. Department of Finance Canada and Revenue Canada (1997) estimated compliance costs of tax credits to be about 10 to 15\% (of the value of the R\&D tax credit claimed) for SMEs and 5.5\% for large firms. Incorporating them to measures of additionality may have a significant impact. However this should be done in a comparative way, taking into account similar costs (that can be much higher) for direct project-based 
subsidies ${ }^{14}$. This is confirmed by studies conducted in the Netherlands (Netherland's Ministry of Finance, 2002) and Norway (Cappelen et al., 2008).

Including administrative and compliance costs also applies to direct measures (where there are nearly no evaluation that has raised this issue). One can anticipate that direct measures entail far higher administrative and compliance costs, especially when account is taken of both public and private administrative costs. This might well counterbalance the 'welfare loss' highlighted by Lokshin and Mohnen (2012) for volume-based tax credits (see 5.1.2 above). Thus it would be important, before deriving any conclusion about the interest of this policy instrument that comparisons are made about the effects of direct and indirect measures on a similar footing.

\section{Conclusions}

Governments increasingly use R\&D tax incentives as a policy tool to support business R\&D. The main rationale for this instrument is to compensate for limited appropriability of private $R \& D$ due to knowledge spillovers. By granting a tax reduction depending on either the volume or increase in a firm's R\&D expenditure, governments co-finance private R\&D. For long time, the key objective of $R \& D$ tax incentives was to raise business $R \& D$ expenditure, and most evaluations analysed the effectiveness of this instrument based on input additionality. In recent years, fiscal incentives have increasingly by used to target other policy objectives as well, including the support of small and young firms, strengthening of industry-science linkages and promoting R\&D in certain thematic areas. Governments also often expect impacts from R\&D tax incentives on the competitiveness of their industry, and regard fiscal incentives as a tool to improve the international attractiveness of their country as a location for innovation. Evaluations of output additionality of tax incentives are rather scarce, however, and little is yet known about the welfare effects in the long run.

Most evaluations find significant input additionality for R\&D tax incentives in the short run. The magnitude of these positive input effects varies a lot, depending on the country and the period considered and the econometric method applied. Positive effects are found for different types of R\&D tax incentives, including both volume-based and incremental schemes as well as for tax credits, tax allowances and for schemes that address corporate taxes and social security contributions. One may thus conclude that $R \& D$ tax incentives are a useful tool to stimulate private R\&D and raise the level of business R\&D expenditure to a higher level. With respect to design features of R\&D tax incentives, volume-based incentives and tax credits tend to produce higher additionality, as holds for more generous schemes (i.e. when a higher share of R\&D activities can be used to reduce a firm's tax burden).

A recent longitudinal study on the welfare effects of the Dutch WSBO scheme - a volume-based tax credit programme - (Lokshin and Mohnen 2012) suggests, however, that input additionality diminishes over time, and that crowding out of private R\&D can only be avoided for small firms while for large firms the scheme turned out to be ineffective. This finding would suggest to differentiating $R \& D$ tax incentives by firm size or the volume of R\&D expenditure, e.g. through introducing caps or applying different rates. In addition, a tax incentive could be lowered for firms that have used the credit for some time.

14 Discussion at Paris workshop (3-4 November 2011) 
Studies on the effects of R\&D tax incentives on innovation success and firm performance tend to find positive effects on a firm's probability to introduce new products and new processes, though the findings on the degree of novelty of these innovations vary a lot. At the same time, there is no clear evidence on the firm level that using an R\&D tax incentive raises productivity or other measures of firm performance. This result may indicate that R\&D tax incentives stimulate R\&D projects with a lower marginal rate of return so that productivity impacts of these projects are minor.

Despite a growing number of sophisticated and reliable studies on the impacts of R\&D tax incentives, our knowledge about the effectiveness of R\&D tax incentives remains limited. Most studies refer to programme effects that emerged in the 1980s and 1990s while little is known about the effects of recently introduced or redesigned fiscal incentive schemes which often show different design features compared to older programmes. While a certain time lag between the implementation of a policy measure and the evaluation of its impact is unavoidable, this time lag is considerably large for fiscal incentive measures as administrative data from tax authorities on the use of R\&D tax incentives have to be merged with other firm data of $R \& D$, innovation and performance. Most empirical studies use data from the manufacturing sector while analyses on the impacts for service firms are rare. In addition, there are very few cross-country comparisons on the effectiveness of R\&D tax incentives, so that it remains difficult to assess the role of country-specific effects for evaluation results. Furthermore, results seem to be sensitive to the empirical approach used, the variation in results for the same country can be quite significant. What is more, very little is known about the interaction between R\&D tax incentives and direct subsidies for R\&D.

The effectiveness of R\&D tax incentives has long been evaluated against input additionality. At the end of the day, however, governments adopt and maintain R\&D tax incentives not to raise R\&D expenditure, but to foster firms' innovative activities and raise social welfare. The use of R\&D tax incentives as a policy tool thus rests on the assumption that innovative capabilities of firms are triggered by R\&D, which is mostly true for manufacturing, but less for services. As services become more and more important for an economy's innovation and productivity performance, the R\&D-innovation link becomes challenged. In addition, in a globalised world R\&D performed in a certain country need not necessarily induce innovation and productivity gains in the same country. Particularly large multinational corporations optimise their innovation processes globally and transfer R\&D results around the globe for commercialising knowledge at those locations and promise the highest returns.

Against these findings from the literature, the role of R\&D tax incentives in a government's portfolio of policy instruments to stimulate $R \& D$ and innovation has to be reconsidered. There are both arguments in favour of R\&D tax incentives, as there are clear limitations of this instrument. The main advantages may be summarised as follows:

- A tax incentive scheme tends to produce lower allocative distortions compared to direct R\&D subsidies since it does not prefer particular technology areas and does not interfere with market mechanisms. Some regulations, e.g. the preferential treatment of SME or higher deductions for certain fields of R\&D activities, do however counteract this neutral feature of tax incentive mechanisms. 
- There is a lower selectivity in terms of firms and industries since R\&D tax incentives are also available to smaller enterprises and enterprises which are not targeted by direct means of R\&D funding (e. g. low-tech industries or services).

- R\&D tax incentives, if implemented on a long-term base, are easier to predict in terms of enterprises' financial planning. There is no uncertainty about the success of applications for direct R\&D grants. They further seem to have lower administrative and compliance costs (however high they are, especially for SME) that for direct subsidies.

- Specific components of the tax incentive scheme, e.g. stimulation of cooperation or the preference for SMEs, are easy to implement as tax incentives are highly accepted in the policy area.

On the other hand there are also some disadvantages to the introduction of R\&D tax incentives.

- The government faces a significantly higher uncertainty of budget consequences compared to direct R\&D funding (France is a clear illustration of such a situation)

- As tax incentives constitute exemptions in the tax law, they complicate the tax system. Yet, a very simple design of the tax incentive scheme can provide the opportunity to relabel certain activities as R\&D. To prevent this, both a differentiated definition of eligible R\&D expenditure and a sufficiently high degree of monitoring need to be implemented.

- Volume-based tax incentive schemes allow firms to deduct the tax payment even for R\&D activities that would have been carried out anyways. Consequently, they provide lower additionality of business R\&D as fine-tuned, project-based support.

The present report cannot provide unambiguous evidence on whether or not to adopt an R\&D tax inventive. When only considering returns on the level of R\&D expenditure, the studies (whatever their limitations are) drive to consider it as a significant element in a policy portfolio. But the coverage (in term of firms and of R\&D levels) and the level of generosity (the definition of activities covered, the level of overheads selected, the level of the reduction and its portability) remain highly contextual and a true political choice. Quite a number of policy debates in various countries highlight the potential role of R\&D tax incentives for increasing a country's attractiveness as a location for corporate R\&D centres both in a defensive (keeping existing activities in the country) and in an offensive way (attracting new R\&D activities by foreign firms). The French Parliament (French Assemblée Nationale 2010) has gathered some evidence of such a role. Using R\&D tax incentives in such a way will work only until other governments adopt the same approach. There is a clear and growing risk of a zero-sum game based upon lower levels of revenues for all governments while the global level of R\&D activities remains unchanged. This in a way is exemplified by the US situation: now that about 40 US states have introduced state $R \& D$ tax credits, the measure is no longer an incentive but a prerequisite, while public returns have diminished. 


\section{References}

Alcacer, I. and W. Chung, 2007. Location strategies and knowledge spillovers. Management Science. (53):760-776.

Arque-Castells P. and P. Mohnen, 2011. How can subsidies be effectively used to induce entry into R\&D? Micro-dynamic evidence from Spain, International workshop on R\&D Policy Impact Evaluation: Methods and Results, organised by Université Paris 1, ICN Business School and CREST with the support of the French Ministry for Higher Education and Research, Paris November 3 and 4.

Berger, P., 1993, Explicit and implicit effects of the R\&D tax credit. Journal of Accounting Research (31):131-171.

Bloom N., R. Griffith and J. van Reenen, 2002, Do R\&D tax credits work, Evidence from a panel of countries 1979-1997. Journal of Public Economics. (85):1-31.

Bloom N. and R. Griffith, 2001, The internationalisation of UK R\&D. Fiscal Studies. (22):337-355.

Bozeman B and J.S. Dietz, 2001. Research Policy Trends in the United States, in Laredo P. and Mustar P. (eds), research and innovation policy in the new global economy, an international comparative analysis. Edward Elgar: Cheltenham, pp. 47-78.

Branstetter, L. G., R. Fisman and C. F. Foley, 2006, Do stronger intellectual property rights increase international technology transfer? Empirical evidence from US firm-level panel data. Quarterly Journal of Economics. (121):321-349.

Caiumi A., 2011. The evaluation of the effectiveness of tax expenditures: a novel approach. An application on the regional tax incentives for business investment in Italy, conference paper, International workshop on R\&D Policy Impact Evaluation: Methods and Results, organised by Université Paris 1, ICN Business School and CREST with the support of the French Ministry for Higher Education and Research, Paris November 3 and 4.

Cappelen, A., A. Raknerud and M. Rybalka, 2007. The effect of R\&D tax credits on firm performance. Report 2007/22. Statistics Norway: Oslo.

Cappelen, A., A. Raknerud and M. Rybalka, 2008, The effects of R\&D tax credits on patenting and innovations. Discussion Paper No. 565/2008. Statistics Norway: Oslo.

Colombo, M. G., L. Grilli and S. Murtinu, 2011. R\&D subsidies and the performance of high-tech start-ups. Economics Letters. (112):97-99.

Corchuelo, M. B. and E. Martinez-Ros, 2009. The effects of fiscal incentives for R\&D in Spain. Working Paper 09-23, Business Economic Series 02, Universidad Carlos III de Madrid.

Criscuolo, C., D. Czarnitzki, C. Hambro and J. Warda, 2009. Design and evaluation of tax incentives for business research and development: Good practice and future developments. Report to the European Commission - DG Research, Brussels.

Czarnitzki, D., P. Hanel and J. M. Rosa, 2011. Evaluating the impact of R\&D tax credits on innovation: A microeconometric study on Canadian firms. Research Policy. (40):217-229.

Dagenais, M., P. Mohnen and P. Thierrien, 1997. Do Canadian Firms Respond to Fiscal Incentives to Research and Development. CIRANO Scientific Series, No. 97-34. 
Department of Finance Canada and Revenue Canada, 1997. The Federal System of Income Tax incentives for Scientific Research and Experimental Development: Evaluation Report. Ottawa: Department of Finance.

Duguet, E., 2010. The effect of the R\&D tax credit on the private funding in R\&D: An econometric evaluation on French firm level data. Working Paper.

Eisner, R., S. H. Albert and M. A. Sullivan, 1984. The new incremental tax credit for R\&D: Incentive or disincentive? National Tax Journal (37):171-185.

Falk, R., J. Borrmann, N. Grieger, E. Neppl-Oswald, U. Weixlbaumer. 2009a. Tax Incentive Schemes for R\&D. Part 4 of the Evaluation of Government Funding in RTDI from a Systems Perspective in Austria, Vienna: Austrian Institute for Economic Research.

Falk, R., E. Neppl-Oswald, K. Trebicka, U. Weixlbaumer. 2009b. Kohärenz des Instrumentenmix: Zusammenspiel der direkten und indirekten Forschungsförderung [Coherence of Policy Mix: Interaction of direct and indirect R\&D support measures], Part 8 of the Evaluation of Government Funding in RTDI from a Systems Perspective in Austria, Vienna: Austrian Institute for Economic Research.

French Assemblée Nationale, 2010. Rapport d'information en conclusion des travaux de la mission d'évaluation et de contrôle sur le crédit d'impôt recherche, rapport $n^{\circ} 2686,30$ Juin 2010, Paris. 214 p.

Hægeland, T. and J. Møen, 2007. Input additionality in the Norwegian R\&D tax credit scheme, Reports 2007/47. Statistics Norway: Oslo.

Hall, B.H., 1993. R\&D tax policy during the eighties: Success or failure? In: Poterba, J. (ed.) Tax Policy and the Economy, Vol. 7, pp. 1-36.

Hall, B.H. and J. van Reenen, 2000. How effective are fiscal incentives for R\&D: A review of the evidence, Research Policy (29):449-469.

Hines, J.R., Jr., 1994. No place like home: Tax incentives and the location of R\&D by American multinationals. In: Poterba, J. M. (Ed.), Tax Policy and the Economy, Volume 8, MIT Press: 65-104.

Hines, I.R., Ir., 1993. On the sensitivity of R\&D to delicate tax changes: The behavior of U.S. multinationals in the 1980s. In Giovannini, A., Hubbard, R.G., Slemrod, J. (Eds.), Studies in International Taxation, Ill. University of Chicago Press, Chicago:149-94.

Klassen, K.J., J.A. Pittmann and M.P. Reed, 2004. A Cross-National Comparison of R\&D Expenditure Decisions: Tax Incentives and Financial Constraints. Discussion Paper, University of Waterloo.

Klette, T. I., I. Møen and Z. Griliches, 2000. Do subsidies to commercial R\&D reduce market failures? Microeconometric evaluation studies. Research Policy (29):471-495.

Kumar, N., 2001. Determinants of locations of overseas R\&D activities of multinational enterprises: The case of US and Japanese corporations. Research Policy (30):159-174.

Lokshin, B. and P. Mohnen, 2012. How effective are level-based R\&D tax credits? Evidence from the Netherlands. Applied Economics 44(12): 1527-1538. 
Mairesse, I. and B Mulkay, 2004. Une Evaluation du Crédit d'Impôt Recherche en France, 19801997, Working Paper No. 2004-43, Institut National de la Statistique e des Etudes Economiques.

McCutchen, W.M. Jr., 1993. Estimating the impact of the R\&D tax credit on strategic groups in the pharmaceutical industry. Research Policy. (22):337-351.

McKenzie, K.J. and N. Sershun 2010. Taxation and R\&D: An investigation of the push and the pull effects. Canadian Public Policy. (36):307-324.

Negassi S., Sattin J.F., 2011. A survey of R\&D Policy evaluations (focused on fiscal incentives), conference presentation, International workshop on R\&D Policy Impact Evaluation: Methods and Results, organised by Université Paris 1, ICN Business School and CREST with the support of the French Ministry for Higher Education and Research, Paris November 3 and 4.

Netherland's Ministry of Finance, 2002. Samenwerken en stroomlijnen, opties voor een effectief innovatiebeleid, Eindrapportage IBO Innovatiebeleid, Den Haag.

OECD, 2002. Frascati Manual: Proposed Standard Practice for Surveys on Research and Experimental Development, 6th Edition ed. OECD, Paris.

OECD, Eurostat, 2005. OECD Proposed Guidelines for Collecting and Interpreting Technological Innovation Data: Oslo Manual 3rd Edition. OECD, Paris.

OECD, 2009. Science, Technology and Industry Scoreboard 2009. OECD, Paris.

OECD, 2010. R\&D tax incentives: Rationale, design, evaluation. OECD Innovation Policy Platform, November 2010.

OECD, 2011a. The international experience with R\&D tax incentives. Testimony by the OECD to the United States Senate Committee on Finance, September 2011.

OECD, 2011b. Science, Technology and Industry Scoreboard 2011: Innovation and growth in knowledge economies. OECD, Paris.

Oxera, 2006. Feasibility study for potential econometric assessment of the impact of R\&D tax credits on R\&D expenditure, HM Revenue and Customs Research Report 19, Oxford.

Parsons, M. and N. Phillips, 2007. An evaluation of the federal tax credit for scientific research and experimental development. Working Paper No. 2007-08, Department of Finance, Canada.

Poot, T., P. den Hertog, T. Grosfeld and E. Brouwer, 2003. Evaluation of a major Dutch Tax Credit Scheme (WBSO) aimed at promoting R\&D, Discussion Paper, TU Delft.

van Pottelsberghe, B., P. Boekholt, F. Cherbonnier, T. Geary, T. Grosfeld, H. Hoefner, G. Hutschenreiter, P. Lanser, G. Licht, P. Mohnen and I. F. Sanz, 2003. Improving the effectiveness of public support mechanisms for private sector research and development. Report to the European Commission, DG Research, Brussels.

Thursby, I. and M. Thursby, 2006. Here or there? A survey of factors in multinational R\&D location. The National Academies Press, Washington, DC.

Warda, J., 2001. Measuring the Value of R\&D Tax Treatment in OECD Countries, OECD STI Review No. 27. 
Wilson, D. I., 2009. Beggar thy neighbour? The in-state, out-of-state, and aggregate effects of R\&D tax credits, The Review of Economics and Statistics (91):431-436.

von Zedtwitz, M. and O. Gassmann, 2002. Market versus technology drive in R\&D internationalization: Four different patterns of managing research and development, Research Policy (31):569-588. 


\section{Manchester Institute of Innovation Research}

The Manchester Institute of Innovation Research (MloIR) is the research centre of excellence in the Manchester Business School (MBS) and The University of Manchester in the field of innovation and science studies. With more than $\mathbf{5 0}$ full members and a range of associated academics from across the University, MloIR is Europe's largest and one of the World's leading research centres in this field.

The Institute's key strengths lie in the linkage and cross-fertilisation of economics, management and policy around innovation and science. Building on forty years of tradition in innovation and science studies, the Institute's philosophy is to combine academic rigour with concrete practical relevance for policy and management. This includes broad engagement with and research for policy makers and societal and industrial stakeholders in the Manchester City Region, across the UK and internationally. MloIR is also firmly committed to a range of teaching activities within and beyond MBS and integrates a strong and successful PhD programme into its research activities. The Institute has a visitor programme for academics and management and policy practitioners and provides a range of popular and high level executive education courses on evaluation, foresight and S\&T Policy. 